\title{
Physiology of the Neonatal Gastrointestinal System Relevant to the Disposition of Orally Administered Medications
}

\author{
April Neal-Kluever, Jeffrey Fisher, Lawrence Grylack, Satoko Kakiuchi-Kiyota, and Wendy Halpern \\ US Food and Drug Administration, Center for Food Safety and Applied Nutrition, College Park, Maryland (A.N.-K.); US Food and \\ Drug Administration, National Center for Toxicological Research, Jefferson, Arkansas (J.F.); Independent Consultant, Vienna, \\ Virginia (L.G.); and Genentech Inc., South San Francisco, California (S.K.-K., W.H.)
}

Received September 10, 2018; accepted December 14, 2018

\begin{abstract}
A thorough knowledge of the newborn (age, birth to 1 month postpartum) infant's gastrointestinal tract (GIT) is critical to the evaluation of the absorption, distribution, metabolism, and excretion (ADME) of orally administered drugs in this population. Developmental changes in the GIT during the newborn period are important for nutrient uptake as well as the disposition of orally administered medications. Some aspects of gastrointestinal function do not mature until driven by increased dietary complexity and nutritional demands later in the postnatal period. The functionalities present at
\end{abstract}

\section{Introduction}

This review is part of a multisector collaborative research effort coordinated by The Health and Environmental Sciences Institute to increase the knowledge base in the nonclinical neonatal space to better inform clinical treatment decisions made for the newborn patient population (De Schaepdrijver et al., 2018). In the area of juvenile animal testing for safety, one challenge is the selection of an appropriate species to evaluate. Ultimately, information on the cross-species ontogeny of factors contributing to drug absorption, distribution, metabolism, and excretion (ADME) processes can help to guide the development of drugs for potential use in neonates.

We aim to provide an overview of the basic ADME functionality present in the gastrointestinal tract (GIT) at birth in term and preterm neonates and compare these functions to those of common animal models used in nonclinical safety assessment. We particularly focus on developmental differences related to ADME functionality in the human and animal neonatal stomach, small intestine, large intestine, and microbiome. Similarly, the maturation of the cross-species ontogeny of ADME-related processes in the liver, and other organs, will be covered in future reviews.

The development of the GIT is recognized as an important contributor to physiologic differences driving pharmacokinetics in children, and

No potential conflicts of interest relevant to this article are reported. https://doi.org/10.1124/dmd.118.084418. birth, and subsequent maturation, can also impact the ADME parameters of orally administered compounds. This review will examine some specific contributors to the ADME processes in human neonates, as well as what is currently understood about the drivers for their maturation. Key species differences will be highlighted, with a focus on laboratory animals used in juvenile toxicity studies. Because of the gaps and inconsistencies in our knowledge, we will also highlight areas where additional study is warranted to better inform the appropriate use of medicines specifically intended for neonates.

ABBREVIATIONS: ADME, absorption, distribution, metabolism, and excretion; ASBT, apical sodium-dependent bile transporter; CES, carboxylesterase; EGF, epidermal growth factor; GIT, gastrointestinal tract; GW, gestational week; IGF, insulin-related growth factor; MRP, multidrug resistance-associated protein; OCT, oral-cecal transit; P450, cytochrome P450; PBPK, physiologic-based pharmacokinetic; PEPT1, peptide transporter 1 ; PND, postnatal day; SITT, small intestinal transit time; $t_{1 / 2}$, half-time; UGT1A1, uridine diphosphate-glucuronosyltransferase $1 \mathrm{~A} 1$. 
and absorptive capacities, prolonged gastric emptying times, and limited intestinal motility compared with the term neonate, among other important differences (Bourlieu et al., 2014; Poquet and Wooster, 2016). These same limiting factors that contribute to a nutritional crisis alter the response of the premature neonate to orally administered therapeutic agents (Mooij et al., 2012).

In addition to the extensive knowledge of GIT development in humans, reflecting both nutritional and medical expertise, there have also been reviews of assessments in animals to investigate the comparative ontogeny of specific components of the neonatal GIT (Henning, 1981; Walthall et al., 2005; Drozdowski et al., 2010; Downes, 2018). There are critical species differences in both GIT maturation at birth, and the primary nutritional needs of the neonate. The combined data from humans and animals have been used to build a more complete picture of the sequence of developmental events in the GIT surrounding the neonatal period and contributing to the complexity of ADME in the neonate.

Historically, the use of drugs in neonates is often "off-label" and based on an empirical application of available knowledge balanced by the immediate needs of these patients (Laughon et al., 2014; Skinner, 2014; Cuzzolin and Agostino, 2016). In the neonatal intensive care unit setting, drug use is primarily guided by published case reports or extrapolation of information from labels for these drugs in the older child or adult patient populations, rather than specific drug labeling for neonates. Examples include anesthetics, anticonvulsants, antireflux drugs, antiarrhythmics and other cardiac drugs, antibiotics, antivirals, analgesics/antipyretics, and diuretics (Laughon et al., 2014; Cuzzolin and Agostino, 2016). The ability to monitor drug levels, as well as specific pharmacodynamic effects potentially allows for safer and more efficient use of drugs in the newborn population. It is uncommon for a drug or biologic to be studied sufficiently in newborns to warrant the inclusion of data and instructions for use in an existing label or to support a "de novo" label. Because of the variability of ADME characteristics in immature and/or sick newborns, and the frequent use of multiple drugs in this population, there is a relatively increased risk of adverse drug reactions. Unfortunately, because of the variety and high frequency of morbidities in this population overall, it is often difficult to assign causality in relation to drug use.

During the last 20 years, based in part on legislative initiatives, there has been a collaborative effort among the Food and Drug Administration, the National Institutes of Health, the pharmaceutical industry, and academic institutions to conduct more research on drug use in children, including newborns, leading to additional labeling of drugs for use in patients in this age range. Although many drugs currently used in sick neonates are preferentially administered parenterally, the oral route remains of interest for drug development and for nonclinical safety testing.

There are a number of factors in the neonatal GIT that could influence ADME properties of drugs and are discussed in this review. These include gastric acid production, gastric residence time or emptying, production of intestinal bile salts, mucosal structure, epithelial permeability to macromolecules, absorptive surface area, intestinal transit time, transporter functionality, biotransformation reactions, digestive enzyme activity, and establishment of the postnatal microbiome. Many of these factors, as they are understood, can then inform the success of in silico, in vitro, and in vivo approaches to better predict the ADME of drugs and chemicals administered to neonates.

\section{The Developing Gastrointestinal System Dynamically Responds to Feeding}

The neonatal gastrointestinal system undergoes dramatic changes in response to enteral feeding. A gastrointestinal growth spurt occurs in the first 24 hours after birth, largely driven by the trophic effect of enteral nutrition (Commare and Tappenden, 2007). Indeed, early feeding with non-nutritive (water alone) fluid delays the development of enteric motor activity, impairs gastrointestinal growth, and slows clinical progress (Berseth and Nordyke, 1993; Commare and Tappenden, 2007). At least partial (or "minimal") enteral feeds are achievable in some preterm infants as early as 25 GWs (Commare and Tappenden, 2007; Neu, 2007). However, preterm infants of less than $32 \mathrm{GWs}$ often are not able to fully use enteral nutrition because of the lack of a suck-swallow reflex, lack of digestive capacity, and limited intestinal motility (Commare and Tappenden, 2007; Neu, 2007). In practice, preterm infants are given parenteral nutrition until enteral feeding is tolerated (Harding et al., 2017). In the preterm neonate, partial enteral feeds of human milk and, to a lesser extent, infant formula have been associated with faster achievement of full enteral feeds, decreased gastrointestinal permeability (Shulman et al., 1998a), and stimulation of intestinal lactase (Shulman et al., 1998b). Enteral feeding of either human milk or formula facilitated the maturation of the intestine in premature neonates by promoting enteral motor activity (Berseth, 1992; Berseth and Nordyke, 1993). Minimal and full enteral feeding of infant formula or human milk has been shown to decrease the incidence of necrotizing enterocolitis and other gastrointestinal complications (Schanler et al., 2005; Commare and Tappenden, 2007; Neu, 2007), although a greater protective effect may be associated with human milk (Schanler et al., 2005).

Several reviews on the maturation of the human infant digestive capacity, including that of premature infants, have been published recently (Bourlieu et al., 2014; Poquet and Wooster, 2016).

In other mammals, the GIT also undergoes immediate changes in response to the initiation of enteral feeding, as has been reviewed (Henning, 1981; Lebenthal and Lebenthal, 1999; Drozdowski et al., 2010; Buddington and Sangild, 2011; Downes, 2018). Studies of human and rat fetal intestinal xenografts point to a mixture of "preprogramming" events that occur regardless of diet, hormonal factors, and milkderived trophic and nutritional factors that, in combination, advance the maturation of the neonatal GIT (Henning, 1981; Montgomery et al., 1981; Winter et al., 1991; Savidge et al., 1995). Ultimately, the bursts of gastrointestinal developmental activity that accompany birth and weaning are driven by environment (diet), hormones and genetic factors. Some species, such as humans and pigs, show pronounced changes, mainly in the immediate perinatal period, whereas more altricial species (e.g., rats) have more protracted postnatal development of the GIT, with the most pronounced changes occurring just prior to and around the time of weaning (Johnson, 1985; Mubiru and $\mathrm{Xu}, 1998$; Sangild, 2006).

It should be noted that the gastrointestinal ontogeny of laboratory species varies in important ways. For example, the rat fetal pancreas accumulates zymogens in late gestation and then releases them with the onset of suckling. Because of this release, the neonatal rat pancreas actually has a marked decrease in size and in relative enzyme activity over the first 3 days of life, despite there being an increase in the number of cells in the pancreas (Mubiru and Xu, 1998). In contrast, in the pig there is a marked increase in absolute and relative pancreatic weight during the first 3 days postnatally. Pig colostrum contains relatively high levels of epidermal growth factor (EGF), insulin-related growth factor (IGF)-I and IGF-II; therefore, rapid development of the pancreas is thought to be driven in part by these colostral growth factors, in addition to the higher levels of neonatal glucocorticoids compared with rats (Mubiru and Xu, 1998). Other studies have also demonstrated a clear role for neonatal feeding and hormones in the digestive capacity of the neonatal pig (James et al., 1987; Tivey et al., 1994; Burrin et al., 2001; Sangild et al., 2002) (Tables 6 and 7). 


\section{Morphology and Function of the Neonatal GIT}

Oral drug absorption in human pediatric populations has been discussed in several reviews (Edginton, 2010; Nicolas et al., 2017). Nutrient absorption in neonates has been very well studied and described. There are many reviews on the current understanding of absorption of carbohydrates (Neu, 2007), amino acids (Kalhan and Bier, 2008), and lipids (Lindquist and Hernell, 2010; Bourlieu et al., 2014; Poquet and Wooster, 2016). Fat digestion and absorption are different in the neonate compared with individuals of older lifestages, and the preterm infant exhibits differences from the term infant (Bourlieu et al., 2014; Poquet and Wooster, 2016). Preterm infants tend to absorb much less fat than term infants, although the biologic reasons for preterm malabsorption of fat are not entirely clear (Lindquist and Hernell, 2010).

\section{Sites of Absorption in the Neonate}

In the neonate, the absorption of chemicals from oral administration may occur in three different physiologic locations: stomach, small intestine, and colon. Drug absorption in the stomach is largely dependent upon gastric $\mathrm{pH}$ and gastric emptying time. Other factors, such as gastric volume, mucin production, and gastric lipolysis may also impact absorption to a lesser degree, depending on drug physiochemical properties. Species differences in gastric anatomy and physiology may result in differences in drug absorption in neonates across species. For example, the rat neonatal stomach resembles intestinal mucosa at birth, with greater absorptive capacity than neonatal pigs, nonhuman primates, and humans (Picut and Coleman, 2016). Thus, theoretically, neonatal rats may have higher gastric absorption of some drugs and chemicals than neonates of other species, and may overpredict gastric absorption of human neonates. Most enterally administered therapeutics and chemicals are absorbed in the small intestine, through passive or active processes. Similar to gastric absorption, passive intestinal absorption can be modulated by luminal $\mathrm{pH}$, intestinal motility, mucin production, as well as surface area or absorptive capacity. A unique consideration in the neonate (term or preterm) is that the colon can be a site of significant absorption of nutrients and pharmaceuticals, whereas in older children and adults, the colon exhibits less absorptive capacity. Perinatally, the human neonatal colon can absorb nutrients (e.g., glucose and amino acids) in a way not seen in adults (Pácha, 2000). This increase in nutrient absorptive capacity is also seen in neonatal rats and pigs (Buddington and Diamond, 1989), and is associated with the presence of apical brush border hydrolases in the colonic mucosa of humans (Lacroix et al., 1984; Zweibaum et al., 1984) and of rats (FoltzerJourdainne et al., 1989). The regional expression of apical hydrolases in the colon of suckling rats is regulated in part by hormones such as EGF and thyroxine (Foltzer-Jourdainne and Raul, 1990; Freund et al., 1990). It may be a compensatory mechanism in response to the decreased ability of the small intestine to absorb these nutrients in the immediate postnatal period. This is relevant to neonatal ADME considerations because colonic or intravenous administration of therapeutics is often used in human neonatal patients, particularly when gastric or intestinal motility is impaired (Kaye, 2011).

\section{Macromolecular Absorption}

Macromolecular absorption refers to the transfer of large molecules intact across the intestinal epithelium. Importantly, in the neonatal period there may be both active and passive transfer of large molecules and proteins. This developmental window may last hours or days, depending on the species and initiation of enteral feeding, and is a unique feature of the neonatal GIT.

Absorption of Igs. One unique consideration for neonatal absorption relates to Ig transfer from colostrum and milk to the neonate. In rodents and primates (including humans), Ig transfer occurs transplacentally during the last trimester of gestation via the neonatal fragment crystallizable receptor for $\operatorname{IgG}(\mathrm{FcRn})$ and is one source of passive immunity in newborns (Palmeira et al., 2012; Bowman et al., 2013; Moffat et al., 2014). There is an added benefit of Igs secreted into breast milk, which provide both local protection within the GIT, and can be absorbed during a brief postnatal period of small intestinal patency in intact macromolecules like Igs (Vukavic, 1984; Smith et al., 1986; Arevalo Sureda et al., 2016). In humans, IgA is the dominant Ig identified in breast milk (Hurley and Theil, 2011), although IgM and IgG are also present to a variable degree (Ruiz et al., 2017). It is difficult to study systemic Ig absorption from breast milk in human neonates because the Igs secreted into the milk are typically the same as those transferred during late gestation. However, in studies comparing serum Igs of preterm or term infants exclusively fed breast milk or formula, clear evidence of IgG absorption from breast milk was limited to preterm infants (gestational age, 31-33 weeks), and neonates initiate production of IgM and IgA fairly rapidly after birth (Savilahti et al., 1983; Cheng et al., 2012). In addition, gastric digestion substantially reduced human milk Igs in term neonates, but not in premature neonates (Demers-Mathieu et al., 2018). In a recent clinical study of lactating women who had been given a modified (PEGylated) therapeutic monoclonal IgG, only minimal concentrations were identified in breast milk, which supports the specificity of Ig secretion into milk (Clowse et al., 2017). Although the specific differences in colostrum composition and Ig uptake in neonates have not been robustly established, the available nonclinical models are likely to overpredict lactational transfer of macromolecules. For example, species that lack effective transplacental Ig transfer, such as dogs and pigs, have high levels of IgG in colostral milk and rely almost entirely on Ig absorption through the gut in the immediate perinatal period for passive immunity (Chastant-Maillard et al., 2012; Goncharova et al., 2017; Mila et al., 2017; Socha-Banasiak et al., 2017). Ultimately, the absorption of intact proteins in the neonatal period occurs prior to the extensive production of peptidases by the stomach and pancreas. However, even in older infants, the presence of Igs in breast milk can confer some protection and may be altered by disease (Hauschner et al., 2015; Abu-Raya et al., 2016; Arevalo Sureda et al., 2016).

Other Macromolecules. Passive transfer of large molecules in the neonatal intestine is often measured using markers of known molecular weight, such as bovine serum albumin or polysaccharides. The adult rat intestinal epithelium can admit solutes of $5000 \mathrm{Da}$ or less at tight junctions (Pappenheimer and Reiss, 1987; Pácha, 2000), and some molecules may be absorbed by this route (Atisook and Madara, 1991). Passive absorption is higher in infants, with preterm neonates exhibiting higher permeability to polysaccharides than term neonates or adults (Beach et al., 1982). However, intestinal permeability to polysaccharides in premature infants 26-37 GWs of age reached similar levels as term infants by postnatal days (PND) 4-7 (van Elburg et al., 2003).

The exact timing of the point at which passive macromolecular absorption is restricted is unknown in humans but has been characterized in some laboratory species and has been reviewed (Pácha, 2000). In general, macromolecular absorption declines after birth in a speciesdependent manner. In pigs, guinea pigs, and hamsters, macromolecular transport ceases in the first few PNDs (Lecce and Broughton, 1973; Weström et al., 1984b, 1989). In rats and rabbits, macromolecular absorption has been observed through PND 21 (Lecce and Broughton, 1973; Teichberg et al., 1992). Work in pigs shows that macromolecular transport of proteins (bovine serum albumin, ovalbumin, fluorescein isothiocyanate-dextrans) is very high at birth but becomes restricted about 18-36 hours after the introduction of colostrum (Weström et al., 1984a,b). Intestinal permeability of chemicals with molecular weights ranging from 383 to 942 Da (polyethylene glycol 600; PEG 1000; 
fluorescein isothiocyanate) at birth in these piglets was much lower than that of proteins and decreased with increasing molecular weight (Weström et al., 1984a,b, 1989). At 3 weeks of age, the pigs did not appear to passively absorb chemicals greater than $1200 \mathrm{Da}$ (Weström et al., 1989).

Similar studies examining the absorption of chemicals with a range of molecular weights has not been reported for humans. However, as has been reviewed, the scientific consensus is that human neonates would be more similar to neonatal piglets than to neonatal rats regarding passive macromolecular absorption (Downes, 2018).

\section{Bile Salt Impact on Fat Absorption}

As has been extensively reviewed, the bile salt pool of neonates contributes to fat absorption, elimination of bilirubin, GIT maturation, and successful bacterial colonization of the GIT (Skinner, 2014; Cashore, 2017). Although much of the literature has focused on bile production and conjugation in the fetal and neonatal liver, there are elements of GIT development that also contribute to production and enterohepatic circulation of bile salts, as has been reviewed (Ridlon et al., 2014; Karpen and Karpen, 2017). For example, the production of secondary bile acids requires enzymatic modification by colonic bacteria, which develop in parallel with the microbiome postnatally. Also, the amount and type of enteral nutrition may affect bilirubin metabolism in the preterm newborn, with infants receiving inadequate enteral nutrition more likely to endure a more prolonged course of perinatal hyperbilirubinemia. Finally, infants receiving parenteral nutrition have a higher risk of having an elevated direct bilirubin concentration (Klein et al., 2010; Trintis et al., 2010; Jolin-Dahel et al., 2013).

Breast milk in all mammals has a relatively high fat content, and the absorption of both fats and fat-soluble vitamins is important for neonates. However, although primary bile acids are produced by the fetus, these are predominantly taurine conjugation based because the hepatic glycine conjugation reactions have not fully matured at birth (Heubi et al., 1982). Overall, bile acid and bile salt concentrations are relatively low in the intestinal lumen, and neither transportermediated uptake nor enterohepatic bile circulation is fully functional at birth. Within the intestine, the reuptake of bile can occur passively in the neonate as well as via active transport in the distal ileum. In rats, the apical sodium-dependent bile transporter (ASBT) is transiently expressed at birth, then suppressed until 2 to 3 weeks postpartum, after which it contributes to efficient intestinal bile reuptake. However, there is also evidence of bile acid production near adult levels and of bile recirculation in the neonatal period, which may reflect passive uptake in the small intestine (Staggers et al., 1982; Klaassen and Aleksunes, 2010). The relatively neutral gastric $\mathrm{pH}$ in neonates increases the solubility of unconjugated bile acids, facilitating passive uptake. In addition to intestinal pinocytosis and fatty-acid binding protein-based uptake of lipids, including unconjugated bile acids (Stahl et al., 1993), there is some evidence that P-glycoprotein efflux pump (also known as MDR1) may also play a role in bilirubin and bile acid disposition (Watchko et al., 2001). Micellar absorption, as seen in adults, appears once pancreatic lipase activity and bile acid concentrations increase, but the timing of this increase is uncertain. Intestinal bile salt reabsorptive capacity may be impaired in neonates. The increase in bile salt reabsorption occurs earlier in precocious animals, such as guinea pigs, than in altricial animals, such as rats; this is likely related to the increased expression of the active ASBT in the ileal mucosal epithelium (Little and Lester, 1980).

Limited data on gallbladder bile or bile-rich duodenal fluid are available for human infants. Some evidence suggests that lower biliary secretions, resulting in lower luminal concentrations of biliary salts, are a limiting factor in the fat absorption by neonates, particularly preterm neonates (Lindquist and Hernell, 2010). Interestingly, human milk and colostrum contain bile salts, predominately cholate and chenodeoxycholate (Forsyth et al., 1983, 1990), and also a bile salt-stimulated lipase (Freed et al., 1987), so breastfeeding may enhance fat absorption by supplementing the bile salts and lipid digestion in the neonatal intestine.

\section{Role of pH on Absorption}

Gastric Acidity. Human neonatal gastric $\mathrm{pH}$ has been studied extensively over the last 50 years. However, the reported values can vary, and in some cases the conditions of sampling are not reported so that it is impossible to identify whether the $\mathrm{pH}$ represents fasted or nonfasted conditions. This is an important consideration because $\mathrm{pH}$ can change depending on the presence of food and may modulate the absorption of some drugs. We sought to report only data from studies that clearly identified the conditions of sampling in an effort to reduce confusion on this topic.

In human neonates, regardless of gestational age at birth (preterm or term), gastric $\mathrm{pH}$ is elevated at birth (around $\mathrm{pH}$ 7.05) because of fetal ingestion of amniotic fluid, which has a neutral pH (Avery et al., 1966; Miclat et al., 1978; Mooij et al., 2012). However, within a few hours after birth stomach pH drops steadily (Griswold and Shohl, 1925). Even in premature neonates, by 1 week after birth, an average fasting gastric $\mathrm{pH}$ of 3-3.5 was observed (Armand et al., 1996) (Table 1).

Since infants are often in the postprandial state, it is important to consider stomach $\mathrm{pH}$ in both fasting and postprandial conditions. It appears that during the fasting state the infant stomach acidity is similar to that in adults and older children after the first 24 hours after birth. The combined available clinical studies support a trend of low $\mathrm{pH}(2.0-3.0)$ before a meal, increasing to 6.0-6.5 immediately after feeding, and remaining elevated (above $\mathrm{pH}$ 5.0) for at least 50 minutes but returning to low pH within 180 minutes (Bourlieu et al., 2014; Yu et al., 2014). Substantial interindividual variability can be observed in these parameters, as reflected in the ranges of values in Table 1 and references therein.

Humans, rabbits, pigs, and sheep all initiate gastric acid secretion during fetal development, whereas rats, mice, and dogs do not develop acid secretion until after birth (Deren, 1971). Importantly, in rats and mice, hydrochloric acid secretion does not fully develop until the rapid growth of the gastric mucosa around weaning (Walthall et al., 2005; Picut and Coleman, 2016). Thus, the gastric $\mathrm{pH}$ of postnatal rodents may be higher than that observed in neonatal humans (Table 2).

Intestinal Acidity. A single literature report was identified describing the intraluminal $\mathrm{pH}$ of the intestine in neonates (Barbero et al., 1952). However, this early report comprised data from only 15 infants ( 7 fed human milk and 8 fed infant formula) aged 2 weeks to 3 months after birth. Further, no information was provided regarding the maturity of the infants at birth (e.g., term or preterm). The limited data indicate that the infants, regardless of food type, expressed an intraluminal duodenal $\mathrm{pH}$ ranging from 5.8 to 7.0 (Table 1).

Limited information was identified regarding the intestine luminal $\mathrm{pH}$ in neonatal animals. In rats aged PND 9-18, a pH gradient was observed ranging from $\mathrm{pH} 6.2$ in the duodenum to 6.9 in the ileum, and did not appear to exhibit age-dependent changes during this time (Rodewald, 1976). In Göttingen minipigs aged PND 1-28, a similar trend was observed, with increased $\mathrm{pH}$ across the proximal-distal gradient of the small intestine (ranging from around 6.0 to approximately 7.0); however, this gradient was not readily apparent until PND 7 and later (Van Peer et al., 2016) (Table 2).

\section{Gastrointestinal Transit}

Gastric Emptying Time. Gastric emptying time can be affected by the type of enteral food. The gastric emptying time [i.e., half-time $\left(t_{1 / 2}\right)$ ] for infant formula has been reported to be about twice as long as for 
human milk in term infants (78 vs. 48 minutes, respectively) (Cavell, 1979, 1981, 1982) (Table 1). Additionally, some evidence suggests that the emptying pattern for human milk is biphasic, with an initial fast phase, whereas with infant formula the emptying pattern is more linear (Cavell, 1979). Some dietary factors that influence gastric emptying have been identified, such as increasing caloric density (slows emptying), protein type (casein causes slower emptying than whey; extensively hydrolyzed results in faster emptying than nonhydrolyzed or partially hydrolyzed protein), type of fat (medium chain triacyl glycerides were emptied faster than long chain) (Bourlieu et al., 2014). Some factors that did not show an effect on gastric emptying included fortification of milk and temperature differences in the milk (Bourlieu et al., 2014).

Overall, delayed gastric emptying of calorie-containing fluids is observed in neonates relative to adults, and preterm infants may exhibit prolonged emptying times compared with term neonates, although the reported data are highly variable (Bodé et al., 2004; Edginton, 2010; Yu et al., 2014) (Table 1). Water is rapidly emptied, but the emptying time for drugs in neonates is expected to approximate that of milk or formula (Edginton, 2010; Yu et al., 2014). Gastric emptying is a complex process coordinated by antroduodenal contractions, fundic contractions, pyloric sphincter relaxation, and intestinal motor activity (Mooij et al., 2012). Antral motor activity under fasting or feeding conditions did not differ between preterm or term neonates (Berseth, 1992). However, there were significant differences in the proportion of antral clusters associated with duodenal activity, the degree of association of antral and duodenal activity, the frequency of duodenal contractions, the number of duodenal contractions per pulse, and the intraluminal peak pressure of duodenal motility in preterm neonates compared with term neonates (Berseth, 1989, 1990; Mooij et al., 2012). Together, this suggests that proximal duodenal motor activity undergoes postnatal maturation in preterm neonates, whereas antral motor activity appears similar to term infants from GW 29 onward (Mooij et al., 2012).

Interestingly, a large meta-analysis (Bonner et al., 2015) of 66 publications reporting gastric-emptying rates for a range of pediatric ages and variety of food types (e.g., aqueous, liquid, semi-solid, solid) found no evidence of an effect of postnatal age or gestational age on mean gastric-emptying time. This study provides data contrasting with data from older studies that reported slower gastric emptying in neonates relative to older children or adults (described above). It is possible that different analytical methods (e.g., scintigraphic, ${ }^{13} \mathrm{C}$-octanoic breath test, ultrasonographic methods), positioning (prone vs. supine), and feeding administration (oral vs. intubation) may affect gastric-emptying rates and measurements, leading to some variability in reported values, as has been reviewed (Edginton, 2010).

There is relatively little available information on the gastric-emptying rates of maternal milk or colostrum compared with infant formulas evaluated in nonclinical species. The available data suggest that, similar to human neonates, rat and pig neonates show slower gastric emptying rates for formula preparations than for maternal milk or colostrum (Table 2).

Intestinal Transit Time. There are a variety of tests available to measure gastrointestinal and colonic motility in humans, including spectroscopy, ultrasonography, stable isotope tests, and motility capsules (Camilleri and Linden, 2016); however, not all of these techniques are used in pediatric settings. These tests may provide estimates of oral-cecal transit (OCT) (e.g., breath tests) or transit time in specific intestinal segments [e.g., small intestinal transit time (SITT) via capsule radiotransmission]. Fewer techniques have been validated in animals, but they include stable isotope breath tests, motility capsule tests, scintigraphy, bead expulsion, and colonic manometry (Camilleri and Linden, 2016). Larger adult animals, such as pigs, dogs, and rabbits, have been studied rather thoroughly, whereas 


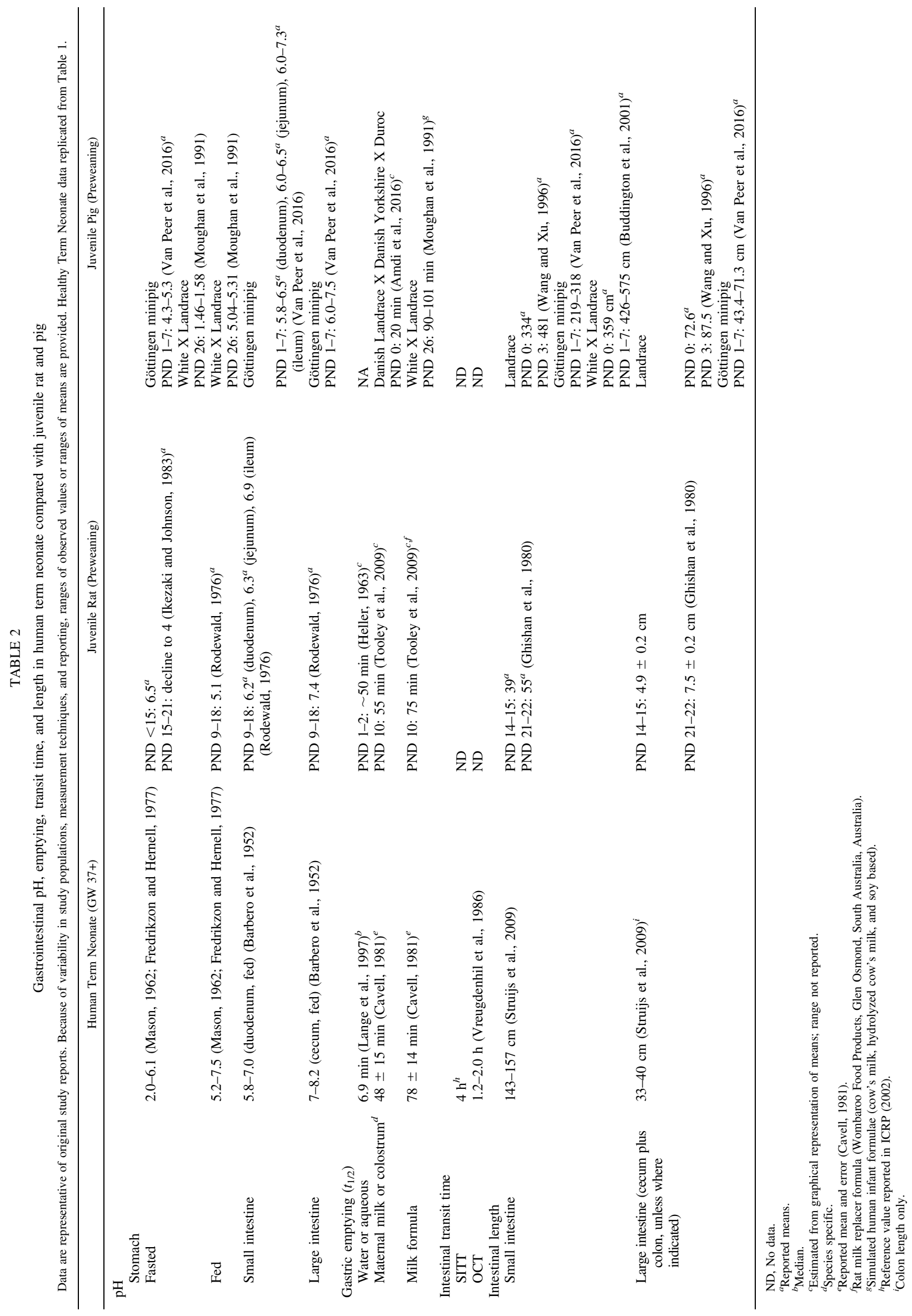


there have been more limited techniques or methodology validated for smaller animals, such as rodents (Camilleri and Linden, 2016). Overall, research in this area is unique in that gastrointestinal transit has been better studied in humans, and with a greater variety of validated test methods, than in nonclinical animal models.

Comparison of available OCT and SITT measurements in pediatric populations ranging from preterm infants born at GW 26 through children 8-14 years of age is complicated by differences in methodologies (Edginton, 2010). A meta-analysis (Maharaj and Edginton, 2016) of more than 40 studies examining OCT or SITT in humans free of intestinal pathology at 6 PNDs of age to 67 years of age did not observe an association of age with either metric after incorporating measures to address differences in measurement techniques. Therefore, the most recent assessment concluded that there was no evidence to suggest that the mean intestinal transit differs between healthy children (including neonates) and adults.

Preterm infant intestinal transit times are generally considered to be four times longer than adult transit times, whereas intestinal transit time in term infants approximates the adult transit time (Bourlieu et al., 2014). Only a single study was identified in the literature that provided an estimate of intestinal transit time in preterm infants (Bodé et al., 2004). In this study, 10 preterm infants (GWs 26-33; PND 6-37) were imaged using scintigraphic methods (technetium ${ }^{99 \mathrm{~m}}$-diethylenetriaminepentaacetic acid) to provide an estimate of OCT. Substantial interpatient variability was observed, with a median OCT of 3.1 hours and a range of 1.36.1 hours. There are physiologic aspects of prematurity that may result in prolonged intestinal transit time. As discussed in Gastric Emptying Time, proximal duodenal motor activity undergoes postnatal maturation in preterm human neonates, whereas antral motor activity appears similar to that in term infants from GW 29 onward (Mooij et al., 2012). Preterm infants exhibit immature intestinal motility and undergo maturational changes involving the enteric motor system during postnatal development (Berseth, 1989). Postprandial motility is absent at GW 31 but appears before GW 35, and enteral feeding of preterm neonates as early as GW 27 can stimulate postprandial motor activity (Berseth, 1989, 1990). One complication in assessing GIT motility in premature infants is the relatively common use of opiates, which also have a direct effect on GI motility, in these patients, especially if they need respiratory support.

We did not identify any published reports that provided quantitative data on the intestinal transit time in neonatal animals. Effort appears to be underway to validate methods and techniques for studying intestinal transit time in animals (Camilleri and Linden, 2016). For example, the use of wireless motility capsules to measure whole gut transit has been validated using dogs and has been studied in large species (e.g., dogs, pigs) (Kvetina et al., 2008; Boillat et al., 2010a,b); however, neonatal data were not available. Additionally, bead expulsion techniques have been used to study colonic motility in mice (Koslo et al., 1986), scintigraphy and manometry have been used to study colonic motility in rats (Spiessens et al., 1988), and fluoroscopic assessment of colonic motility has been conducted in pigs (Hipper and Ehrlein, 2001). Again, neonatal data were not available for these methods in these species. We anticipate that as method development progresses for adult animals, these techniques may ultimately be adapted for use in some neonatal animals. However, physiologic differences between species, including maternal stimulation of elimination in neonates of altricial species, may complicate interpretation.

\section{Intestinal Transporters}

There is significant interest in the ontogeny of intestinal transporters, particularly those related to the uptake or efflux of drugs (Mooij et al., 2012, 2014; Brouwer et al., 2015). However, in the course of writing this review, it became clear that the published literature does not readily facilitate an understanding of the general ontogeny of specific transporters in the human GIT. Manuscripts that report data from neonatal human tissues often vary in how they report the age of the human subjects (e.g., postmenstrual age, gestational age, postnatal age). Furthermore, data obtained from preterm human infants may use other criteria to characterize the sample population, such as birth weight, without also providing a description of gestational or postnatal age. This limited our ability to integrate findings from multiple sources.

In addition to issues with comparing samples across human infant ages, and term versus preterm infant populations, the scientific literature uses a variety of methodology to report transporter activity or expression levels. For example, absorption rates may be obtained using radiotracer methodology in vivo. Alternatively, measurements of expression may be obtained from the levels of mRNA (e.g., reverse-transcription polymerase chain reaction) or protein (e.g., immunohistochemistry or Western blotting). Often the expression level (mRNA or protein) may be reported for an age or age range in infants, but corresponding data in older children or adults were absent.

Finally, receptor ontogeny studies in laboratory models exhibited similar discrepancies and variations. Often only mRNA or protein (not both) was measured as an indication of expression level, and often these data were provided in the absence of activity (in vivo or in vitro measurements). Frequently, only a single postnatal age or age range was studied, and comparison with older animals was not performed. Additionally, in some cases the RNA or protein sampling methodology was fully described, including whether samples were derived from whole tissue or limited to the epithelium. In other cases, this level of detail was not provided. Sampling from whole tissue may be misleading when the target RNA or protein is restricted to the epithelium.

Ideally, there would be data in laboratory animals as well as humans on the expression levels (RNA and protein) as well as activity levels (in vivo or in vitro activity assays) to allow a comparison of the ontogeny of GIT functionality in humans and common laboratory animals. This would allow better understanding of the gastrointestinal uptake of any substance that may be carried by that transporter.

Because of all these considerations, we did not find many cases where there was adequate transporter information for neonates that could be used to inform ontogeny in humans and across species used in nonclinical assessment. A few recent publications have summarized the human ontogeny of drug transporters in the fetus (Fakhoury et al., 2009) and the neonate (Mooij et al., 2014, 2016; Brouwer et al., 2015). Of transporters with affinity for drugs, only peptide transporter 1 (PEPT1) was sufficiently studied in animals to inform cross-species comparisons (Table 3). Interestingly, the activity of nutrient-related transporters in the GIT appears to be better characterized than transporters with affinity for drugs, such as those in the organic anion transporting peptide, organic cation transporters (OCTs), and multidrug resistance-associated protein (MRP) subfamilies. Of the ATP-binding cassette transporter family, the expression of MRP1 and breast cancer resistance protein is relatively stable between infants and adults (Konieczna et al., 2011; Mooij et al., 2014). In contrast, but similar to data for PEPT1, both MRP2 and the OATP2B1 (organic anion transporting peptide 2B1) are higher in neonates than in adults (Mooij et al., 2014). There is also an isolated report of low expression of MRP3 RNA in neonatal rabbits, which increases after weaning (Weihrauch et al., 2006).

In contrast to the sparse data for intestinal drug transporters, there is a robust understanding of the ontogeny of sugar, amino acid, vitamin, and inorganic phosphate transport for neonatal humans and animals, largely driven by the needs of clinical nutrition to optimize infant feeding formulations and strategies, as reviewed previously (Buddington, 1992, 1994; Pácha, 2000; Boudry et al., 2010; Drozdowski et al., 2010; Poquet and Wooster, 2016). In addition, the development of specific bile 
TABLE 3

Ontogeny for absorption of amino acids, dipeptides, and tripeptides

\begin{tabular}{|c|c|c|c|c|}
\hline Species & Transporters & Ontogeny of Oral Absorption & $\begin{array}{l}\text { Sampled GIT } \\
\text { Tissue }\end{array}$ & Reference \\
\hline Human & PEPT1 & $\begin{array}{l}\text { PEPT1 mRNA levels marginally lower } \\
\text { compared with older children }(0.8 \times)\end{array}$ & SI & Mooij et al. (2016) \\
\hline Rat & PEPT1 & $\begin{array}{l}\text { PEPT1 protein and mRNA increase to } \\
\text { elevated levels in immediate } \\
\text { postnatal period then decrease to } \\
\text { adult level }\end{array}$ & SI and colon & $\begin{array}{l}\text { Miyamoto et al. (1996); Shen et al. } \\
\text { (2001); Hussain et al. (2002) }\end{array}$ \\
\hline Dog & $\begin{array}{l}\text { No transporter studies available; } \\
\text { amino acid absorption studies } \\
\text { are available }\end{array}$ & $\begin{array}{l}\text { AA absorption is high at birth and } \\
\text { decreases with PN age }\end{array}$ & SI and colon & Buddington and Malo (2003) \\
\hline $\begin{array}{l}\text { Pig (Yucatan, Tibetan, } \\
\text { LandraceXYorkshire; } \\
\text { Huangjiang) }\end{array}$ & PEPT1; EAAC1 & $\begin{array}{l}\text { AA absorption, mRNA, and protein } \\
\text { levels appear prenatally and peak in } \\
\text { PN period, then decline to adult } \\
\text { levels }\end{array}$ & SI and colon & $\begin{array}{l}\text { Buddington and Malo (1996); Zhang } \\
\text { et al. (1997); Buddington et al. (2001); } \\
\text { (2012); Fu et al. (2013); Nosworthy et al. } \\
\text { (2013); Wang et al. (2013) }\end{array}$ \\
\hline
\end{tabular}

AA, amino acid; EAAC1, excitatory amino acid carrier 1; PN, postnatal; SI, small intestine.

transporters, such as the apical sodium bile transporter in the ileum, is well described for humans and rats (Little and Lester, 1980; Staggers et al., 1982; Karpen and Karpen, 2017).

\section{Gastrointestinal Metabolism}

Metabolism in the intestinal tract refers to processes of breaking down ingested macromolecules (food) for effective absorption and utilization of macronutrients and micronutrients. This primary function of the GIT undergoes substantial postnatal development during the neonatal period, extending through the process of weaning. As detailed in the absorption section above, the maturation of these systems is typically driven by the diet and is initially suitable for milk in neonatal mammals. However, there are important differences in neonatal metabolic capacity between altricial neonates, such as mouse, rat, and dog pups, compared with human neonates.

In specific reference to orally administered drugs, metabolism typically refers to the processes of biotransformation of drugs to facilitate excretion. This occurs via oxidative biotransformation and conjugation reactions to produce a more hydrophilic metabolite of the parent molecule or drug, which then often has decreased pharmacologic activity; sometimes the metabolite is more active or has a different activity, than the parent molecule. Chemically complex drugs may generate a number of metabolites through parallel or serial processes. In mammals, the liver is typically the primary site of such reactions (Klaassen and Aleksunes, 2010; Hines, 2013; Smits et al., 2013), but some biotransformation also occurs within the GIT. In addition to direct effects on biotransformation processes, orally administered drugs may impact pathways important to nutrient metabolism. Therefore, it is important to consider the normal neonatal physiology and the dietary requirements for both human neonates and species used for testing.

\section{Biotransformation and Conjugation}

Ontogeny of Cytochrome P450 Enzymes in Human GIT. Most reviews of cytochrome $\mathrm{P} 450$ (P450) enzyme ontogeny have focused on the liver. However, some intestinal biotransformation also occurs, with most of the information in the literature focusing on the CYP3A subfamily. Expression levels (mRNA and/or protein) and the activities of CYP3A subfamily enzymes in the GIT of fetuses, neonates, infants, and/or young children have been reported, and, in some cases, these levels were compared with adult levels. When the comparison is made across different data sources, caution should be exercised since organ procurement (e.g., "small intestine" or "duodenum"), the sample preparation (e.g., microsome preparation, membrane preparation, or homogenate), and the normalization method used to calculate relevant mRNA or protein expression levels can often vary. In this review, summarized in Table 4, we will simply discuss the presence or absence of enzymes and the relative levels (e.g., high or low) of expression compared with those in older children or adults or other enzymes at specific ranges of developmental or postnatal age. It should be also noted that for some drug-metabolizing enzymes, mRNA may be a reliable surrogate for protein expression levels, but mRNA expression levels may not necessarily correlate with protein expression levels. Also, many of the antibodies used to detect protein (e.g., via Western blot or immunoblotting) in older studies can be unreliable and have been shown to detect numerous P450 isoforms.

In human fetuses, CYP3A4 and CYP3A7 mRNA expression levels are detectable in intestinal tissues as early as the first trimester (Miki et al., 2005; Betts et al., 2015). It is well known that CYP3A7 mRNA expression is significantly higher than CYP3A4 expression in fetal liver. In contrast, in fetal small intestine, CYP3A4 and CYP3A7 mRNA levels were comparable (Miki et al., 2005; Betts et al., 2015). CYP3A5 mRNA expression was also present in fetal duodenum samples and increased from the first trimester until birth (Fakhoury et al., 2009). In infants, including neonates, CYP3A4 and CYP3A5 mRNA expression levels were similar but much higher than those of CYP3A7 in duodenum (Fakhoury et al., 2005). CYP3A4 and CYP3A5 mRNA expression levels were relatively high in the first year of life compared with those in older children ( $>6$ years old) or adults ( $\geq 18$ years old) but decreased with age to reach levels similar to those observed in adults (Fakhoury et al., 2005; Chen et al., 2015).

The ontogeny of CYP3A protein expression in intestinal tissues does not necessarily correlate with the mRNA expression pattern of CYP3A enzymes in fetuses and infants. For example, Chen et al. (2015) indicated a potential increase in translational efficiency in CYP3A4 mRNA with age. The ontogeny CYP3A protein expression has been described using Western blot and immunohistochemistry (Johnson et al., 2001; Fakhoury et al., 2005; Chen et al., 2015). CYP3A4 protein was practically absent in fetal duodenum (mean GW, 13 weeks; GW range, 9-15) (Johnson et al., 2001), and it increased during the first 3 months after birth (Johnson et al., 2001; Fakhoury et al., 2005; Chen et al., 2015) There are inconsistent results reported for duodenum CYP3A4 content (S9 fraction) in infants at $\geq 3$ months postnatal age. Johnson et al. (2001) demonstrated that CYP3A4 protein expression in infants ( $\geq 3$ months postnatal age) already achieved the range of that observed in older children ( $>12$ years old). However, Chen et al. (2015) reported increases in age in CYP3A4 protein up to approximately 11 months postnatal age. 
Similar to protein expression, CYP3A4 activity, determined by duodenum $\mathrm{S} 9$ testosterone $6 \beta$-hydroxylation activity, also showed an increase with age (Johnson et al., 2001). The activity was undetectable in fetal samples (GW mean, 13; GW range, 9-15). Although it was detectable during the first 3 months after birth, the activity level was significantly lower compared with older children ( $>12$ years old).

It should be noted that underlying disease and/or conditions may affect intestinal CYP3A4 protein expression and activity in the pediatric population. Pediatric populations with active (untreated) celiac disease showed markedly decreased CYP3A protein expression and CYP3A4 activity (Johnson et al., 2001). They returned to normal ranges after treatment with a gluten-free diet. In contrast, pediatric patients with cystic fibrosis exhibited no significant differences in duodenal CYP3A protein expression or activities compared with control subjects without disease.

In summary, human fetal protein expression as well as metabolic activity of CYP3A is undetectable, although mRNA is present in intestinal tissues of fetuses as early as the first trimester. Postnatally, CYP3A4 activity is low in neonates but increases with age (Table 4). The specific timing of CYP3A metabolic maturity is not fully understood. As noted above, underlying disease and/or conditions that can affect intestinal CYP3A enzyme expression and activity should also be considered in understanding drug disposition.

There is only limited information about the ontogeny of the CYP2C and CYP2J epoxygenase subfamilies in the human GIT. The expression pattern of CYP2C8, CYP2C9, CYP2C19, and CYP2J2 in human embryonic/fetal intestines at GWs 7-20 has been studied by immunohistochemistry (Cizkova et al., 2014). Cytoplasmic staining of these enzymes in enterocytes was detected as early as GW 7. CYP2C8 and CYP2C9 protein reached levels comparable to adult expression levels at GWs 16 and 14, respectively. Adult levels of CYP2C19 protein were already observed at GW 7, although they was lower than those of CYP2C8 and CYP2C9 during fetal development. The protein expression of CYP2J2 in embryonic and fetal intestine was higher than in adult tissue and remained unchanged during all tested prenatal periods (Table 4).

Although RNA and protein expression levels and catalytic activity of intestinal CYP2C and CYP2J2 enzymes for neonates have not been specifically evaluated, they may contribute to first-pass metabolism of substrates [e.g., nonsteroidal anti-inflammatory drugs reviewed for CYP2C9 (Van Booven et al., 2010), and albendazole reported for CYP2J2 (Lee et al., 2010)], assuming that fetal levels are maintained through the perinatal period. Finally, CYP2D6 is described in the adult intestine but has not been reported for the fetus or neonate.

Ontogeny of Intestinal P450 Enzymes in Animals. Although some P450 enzymes possess relatively high-sequence homology across species, the profile of $\mathrm{P} 450$ enzyme expression can be quite different in animals compared with humans. As has been reviewed, none of the nonclinical species, including monkeys, are completely similar to humans with respect to P450 enzyme activities, substrate specificity, or inhibitor selectivity (Martignoni et al., 2006; Komura and Iwaki, 2011; Emoto et al., 2013).

Differences of CYP3A, CYP2C, and CYP2D in isoforms, expression, substrate selectivity, and catalytic activity across species were nicely summarized previously (Martignoni et al., 2006; Komura and Iwaki, 2011; Emoto et al., 2013). There are also species differences in the induction and inhibition of enzyme activity or expression (Martignoni et al., 2006). Therefore, some caution should be applied when extrapolating metabolism data from animal models to humans.

Patel et al. (1998) investigated the expression of P450 enzyme isoforms in rat fetal and postnatal intestine. Immunoblotting indicated that CYP2B, which was not detected in human adult small intestine 
(Paine et al., 2006), was expressed in fetal and early postnatal rat intestine (Patel et al., 1998). Its expression level was lower than that of adult rats and showed a modest increase up to PND 27. Other P450 enzyme isoforms, including CYP3A, were not detected in either fetal or postnatal rat intestine.

A sharp increase in rat enterocytic CYP3A expression was detected by immunoblotting and testosterone $6 \beta$-hydroxylase activities at weaning (between PND 20 and 30), followed by a plateau up to PND 80 (Johnson et al., 2000). However, this study measured CYP3A expression by densitometry of immunoblotting using a polyclonal goat anti-rat CYP3A2 antibody, and expression levels were much higher ( $~ 80 \mathrm{pmol} / \mathrm{mg}$ protein up to 80 days) than those reported in other studies where CYP3A2 was not detected or was only weakly detected (Patel et al., 1998; Matsubara et al., 2004; Aiba et al., 2005).

A recent study (Hersman and Bumpus, 2014) reported mouse intestinal P450 enzyme protein expression at approximately 1, 2.5, and 8-10 months of age using a mass spectrometry-based proteomics approach. CYP2C29, CYP3A25, and CYP4A12 were detected at all ages at relatively constant levels. CYP4B1 was detected at low levels at up to 2.5 months of age but was not detected at 8-10 months of age. CYP3A13 was detected at 1 month of age but not at older ages, except in males at 2.5 months of age. CYP2C37 was detected in females at 1 month of age and in males at 2.5 months of age. Additionally, CYP3A expression was identified by immunoblotting in mouse small intestine even at 17 days after birth (Zhu et al., 2014).

The presence of CYP3A in the small intestine of fetal, neonatal, juvenile, and adult Göttingen minipigs was investigated by immunohistochemistry (Van Peer et al., 2014). In contrast to human fetal duodenum (Johnson et al., 2001), CYP3A protein was detected at low levels in the villous enterocytes from 86 days of gestation onward in minipig. Low levels of CYP3A expression were observed after birth, but it was increased with age in small intestine during postnatal development, similar to the postnatal expression pattern of CYP3A4 in human intestine (Johnson et al., 2001; Fakhoury et al., 2005; Chen et al., 2015). The majority of 28-day-old animals showed intense cytoplasmic staining, but the staining was still less intense compared with adult minipigs. Ontogeny of other intestinal P450 enzymes in minipig has not been extensively investigated.

In summary, intestinal P450 enzymes in mammals are detectable during gestation and undergo at least some maturation postnatally with regard to mRNA/protein expression levels and activity (Table 4). However, it is difficult to extrapolate a clear pattern of ontogeny and translation because of the sometimes conflicting and different types of data available. There are also some enzymes, such as CYP2D6, which have not been studied in human fetuses or neonates. Likewise, for most nonclinical species only limited information has been generated.

Intestinal Carboxylesterases. As has been reviewed for adults, among two major carboxylesterases (CESs; CES1 and CES2), the human liver predominantly contains CES1 with smaller quantities of CES2, whereas the small intestine contains CES2 with virtually no CES1 (Laizure et al., 2013). Hosokawa (2008) nicely summarized adult intestinal CES1 and CES2 mRNA expressions qualified in preclinical species (Hosokawa, 2008); rodents (mouse, rat, and hamster, but not guinea pig) show a pattern consistent with that of humans. In monkey small intestine, CES1 is expressed in addition to CES2. Contrary to those of humans, rodents, and monkeys, the dog intestine does not contain either CES1 or CES2.

In humans, CES2 mRNA and protein exhibited a postnatal increase (1-332 days of age), and CES2 mRNA expression levels in infants 163-332 days of age were comparable to those of adults ( $\geq 18$ years old) (Chen et al., 2015). Ontogenic expression of intestinal CES2 in preclinical species remains to be established.
Conjugation Reactions in the Neonate. As with P450 enzymes, there has been a focus on the liver for the development of metabolic conjugation reactions, with more limited contributions by the GIT. There have been some review articles describing expressions of glutathione $S$-transferases, $N$-acetyltransferases, epoxide hydrolases, and sulfotransferases in GIT during human fetal development (McCarver and Hines, 2002; Blake et al., 2005; Coughtrie, 2015). However, it appears that little is known about the timing when these enzymes reach adult activity levels. Additionally, only limited information (e.g., ontogeny of sulfotransferases in mouse intestine) (Alnouti and Klaassen, 2006) is available for preclinical species.

In neonates, the conjugation of bilirubin by uridine diphosphateglucuronosyltransferase 1A1 (UGT1A1) is of particular importance, as there is a risk of kernicterus when unconjugated bilirubin accumulates in brain tissue. Neonatal jaundice is common in humans, but not in other mammals studied, and has been linked to both genetic and environmental risk factors. Genetic factors include loss of the gene, mutations leading to loss of function of the UGT1A1 gene, as well as numerous polymorphisms of the UGT1A1 gene (Fujiwara et al., 2015; Cashore, 2017; Kaplan, 2017).

Extrahepatic expression and activity of UGT1A1 in neonates have been reviewed recently and highlight the importance of GI UGT1A1 activity in understanding the neonatal jaundice linked to breastfeeding (Fujiwara et al., 2015). A humanized UGT1A mouse model has been developed to further elucidate the role of GIT UGT1A1 in neonatal humans (Fujiwara et al., 2012, 2015). Further understanding the pathogenesis and drivers of neonatal jaundice in humans remains an area of active study with the limited models available, but also highlights a key difference between neonatal humans and other mammals. Because of these special considerations regarding UGT1A1 activity and the potential for neonatal jaundice, any new drug development for neonatal use must take into account the potential adverse effects on bilirubin metabolism.

\section{Ontogeny of Digestive Enzymes}

Across species the ontogeny of digestive enzymes is highly dependent on the nutrient source and metabolic needs of the species, as has already been reviewed (Walthall et al., 2005; Drozdowski et al., 2010; Downes, 2018). Overall, digestive processes may be less likely to be directly relevant to ADME processes of pharmaceuticals, but they are reviewed at a high level, especially with regard to species differences. Species differences for selected digestive enzymes are summarized by anatomic region in Table 5 (orogastric), Table 6 (pancreatic), and Table 7 (intestine).

In rodents, there is high lipase activity in saliva at birth (lingual lipase), whereas there are negligible contributions from gastric and pancreatic lipase activity at birth (Henning, 1981; Liao et al., 1983; DeNigris et al., 1988). In contrast, gastric lipase is the primary initial contributor to milk lipid digestion at birth in most other species evaluated, including human (Fredrikzon and Hernell, 1977; DeNigris et al., 1988; Iverson et al., 1991).

In the rat, most digestive enzyme activities (parotid amylase, gastric pepsin, and pancreatic chymotrypsin, trypsin, and lipase) are minimal through PND 14, then undergo a sharp increase around the time of weaning (PND 21) (Henning, 1981; Johnson, 1985). This is in contrast with the human, pig, and dog, which have more mature gastric and pancreatic digestive function shortly after birth. The ontogeny of digestive enzymes of the GIT is reviewed in Tables 5 and 6.

The expression and activity of most apical brush border hydrolases and esterases are regulated by both developmental milestones and by diet. For neonates, both the initiation of suckling and milk or formula content contribute, and the enzymes reflect the nutrient content. Intestinal hydrolase activity has been extensively studied in feeding 
TABLE 5

Ontogeny of oral cavity and gastric digestive enzymes

\begin{tabular}{|c|c|c|c|c|}
\hline Enzyme & Human & Rat & Pig & Other \\
\hline Lingual lipase & $\begin{array}{l}\text { Detected by GW } 26 \text { and detected at } \\
\text { birth with subsequent decline } \\
\text { (Hamosh et al., 1981; Fredrikzon } \\
\text { et al., 1982; Smith et al., 1986; } \\
\text { Lee et al., 1993) }\end{array}$ & $\begin{array}{l}\text { Primary source of lipase activity at } \\
\text { birth; mouse is similar (Henning, } \\
\text { 1981; DeNigris et al., 1988) }\end{array}$ & Not specifically described & $\begin{array}{l}\text { For neonatal guinea pigs, rabbits and } \\
\text { baboons, low or no activity } \\
\text { detected (DeNigris et al., 1988) }\end{array}$ \\
\hline Salivary amylase & $\begin{array}{l}\text { Low levels present prenatally and at } \\
\text { birth; adult levels achieved by } \\
3 \text { mo of age (Sevenhuysen et al., } \\
\text { 1984; Shibata et al., 2013; } \\
\text { García-Blanco et al., 2016) }\end{array}$ & $\begin{array}{l}\text { Not detected until second postnatal } \\
\text { week, with substantial increase at } \\
\text { weaning (Redman and Sreebny, } \\
\text { 1971) }\end{array}$ & Not specifically described & $\begin{array}{l}\text { Not specifically described for other } \\
\text { species used for nonclinical drug } \\
\text { development }\end{array}$ \\
\hline Gastric lipase & $\begin{array}{l}\text { Detected by GW } 26 \text { and primary } \\
\text { source of lipase activity at birth } \\
\text { for term and preterm infants; } \\
\text { subsequent decline postnatally } \\
\text { (Sarles et al., 1992; Ménard et al., } \\
\text { 1995; Armand et al., 1996) }\end{array}$ & $\begin{array}{l}\text { Negligible activity at birth for both } \\
\text { rats and mice (DeNigris et al., } \\
1988 \text { ) }\end{array}$ & $\begin{array}{l}\text { Highest in neonatal period } \\
\text { then declines after } \\
\text { weaning (Li et al., 2001) }\end{array}$ & $\begin{array}{l}\text { Primary source of lipase activity in } \\
\text { neonates of most nonrodent } \\
\text { species (pig, dog, rabbit, guinea } \\
\text { pig, baboon) (DeNigris et al., } \\
\text { 1988; Iverson et al., 1991; Carrière } \\
\text { et al., 1992) }\end{array}$ \\
\hline Gastric pepsin & $\begin{array}{l}\text { Present and active at birth; but lower } \\
\text { expression and activity than } \\
\text { adults; activity increases after } \\
\text { initiation of oral feeding (Wagner, } \\
\text { 1961; Agunod et al., 1969; } \\
\text { DiPalma et al., 1991; Armand } \\
\text { et al., 1996) }\end{array}$ & $\begin{array}{l}\text { Not detected until second postnatal } \\
\text { week, then activity increases } \\
\text { through weaning (Deren, 1971; } \\
\text { Furihata et al., 1972; Henning, } \\
\text { 1981) }\end{array}$ & $\begin{array}{l}\text { Low at birth but gradual } \\
\text { increase after 1st week } \\
\text { postnatal (Cranwell, 1985), } \\
\text { and substantial increase at } \\
3 \text { wk (Cranwell, 1985; Smith, } \\
\text { 1988) }\end{array}$ & $\begin{array}{l}\text { In ferrets, low at birth with gradual } \\
\text { rise during first } 3 \text { wk postnatal } \\
\text { (Hamosh et al., 1998); in rabbits } \\
\text { and dogs, low or no activity until } \\
\sim 3 \text { wk (Buddington et al., 2003) }\end{array}$ \\
\hline
\end{tabular}

studies with piglets (de Passillé et al., 1989; Vega et al., 1992; Wang and $\mathrm{Xu}, 1996$; Burrin et al., 2001).

The literature further has established a role for hormones such as thyroxine, cortisol, insulin, EGF, and IGF1, often secreted into colostrum, to influence the transcription, expression, and maturation of these hydrolases (James et al., 1987; Foltzer-Jourdainne et al., 1989; Foltzer-Jourdainne and Raul, 1990; Burrin et al., 2001; Petersen et al., 2002; Lu et al., 2011). These and other studies have demonstrated that several brush border hydrolases are transiently expressed and active in the neonatal colon in addition to the intestine. This has predominantly been studied in the rat (Foltzer-Jourdainne et al., 1989;
Foltzer-Jourdainne and Raul, 1990; Freund et al., 1990) but also has been confirmed in humans (Potter and Lester, 1984; Zweibaum et al., 1984; Foltzer-Jourdainne et al., 1989) and pigs (James et al., 1987; Burrin et al., 2001). For example, both neonatal rats and humans express lactase and lysosomal neuraminidase to help digest milk sugars, and both expression and activity are higher in the suckling period than after weaning. Human infants express a functional sucrase-isomaltase complex by 26 weeks in utero, which prepares the neonate for the relatively high carbohydrate content in human milk. In contrast, rat pups do not express carbohydrate-metabolizing enzymes until about 2 weeks postnatally, and the sucrase-isomaltase complex is not detected

TABLE 6

Ontogeny of pancreatic digestive enzymes

\begin{tabular}{|c|c|c|c|c|}
\hline Enzyme & Human & Rat & Pig & Other \\
\hline Pancreatic amylase & $\begin{array}{l}\text { Negligible activity prenatally } \\
\text { and at birth but detected by } \\
1 \text { mo postnatally and } \\
\text { reaches adult levels by } \\
\text { weaning (Lebenthal and } \\
\text { Lee, 1980) }\end{array}$ & $\begin{array}{l}\text { Present at birth for first feeding, but } \\
\text { then steep decline (Robberecht } \\
\text { et al., 1971; Mubiru and Xu, 1998) }\end{array}$ & $\begin{array}{l}\text { Rapid increase postnatally in } \\
\text { pigs (Mubiru and Xu, 1998) }\end{array}$ & $\begin{array}{l}\text { In dogs, first detected after } 3 \text { wk, } \\
\text { but relatively low through } \\
\text { weaning (Buddington et al., } \\
\text { 2003) }\end{array}$ \\
\hline Pancreatic lipase & $\begin{array}{l}\text { Negligible at birth (Lebenthal } \\
\text { and Lee, 1980) }\end{array}$ & $\begin{array}{l}\text { Present at birth for first feeding, but } \\
\text { then steep decline until weaning } \\
\text { (Robberecht et al., 1971; Mubiru } \\
\text { and Xu, 1998) }\end{array}$ & $\begin{array}{l}\text { Present and active at birth in pigs } \\
\text { with steep increase in activity } \\
\text { at } 3-4 \text { wk; primary source of } \\
\text { lipase activity (Pierzynowski } \\
\text { et al., 1995; Jensen et al., 1997; } \\
\text { Mubiru and Xu, 1998; Li et al., } \\
\text { 2001) }\end{array}$ & $\begin{array}{l}\text { Not detected until } 6 \mathrm{wk} \text {, but } \\
\text { reaches adult levels by } 9 \text { wk } \\
\text { postnatal (Buddington et al., } \\
\text { 2003) }\end{array}$ \\
\hline Carboxypepdidase B & $\begin{array}{l}\text { Relatively low prenatally and } \\
\text { at birth (Lebenthal and } \\
\text { Lee, 1980) }\end{array}$ & & Not specifically reported & \\
\hline Trypsin & $\begin{array}{r}\text { Present and active from birth } \\
\text { (Lebenthal and Lee, 1980) }\end{array}$ & $\begin{array}{l}\text { Present and presumed active at } \\
\text { birth for first feeding, but then } \\
\text { steep decline until weaning } \\
\text { (Robberecht et al., 1971; Mubiru } \\
\text { and Xu, 1998) }\end{array}$ & $\begin{array}{l}\text { Present and active at birth, with } \\
\text { increased activity postnatally } \\
\text { (Harada et al., 1988; Jensen } \\
\text { et al., 1997; Mubiru and Xu, } \\
\text { 1998) }\end{array}$ & $\begin{array}{l}\text { In dogs, relatively high activity } \\
\text { during suckling (Buddington } \\
\text { et al., 2003) }\end{array}$ \\
\hline Chymotrypsin & $\begin{array}{r}\text { Present and active from birth } \\
\text { (Lebenthal and Lee, 1980) }\end{array}$ & $\begin{array}{l}\text { Present at birth for first feeding, } \\
\text { but then steep decline until weaning } \\
\text { (Robberecht et al., 1971; Mubiru } \\
\text { and } \mathrm{Xu}, 1998 \text { ) }\end{array}$ & $\begin{array}{l}\text { Present and active at birth with } \\
\text { increased activity postnatally } \\
\text { (Harada et al., 1988; Jensen } \\
\text { et al., 1997; Mubiru and Xu, } \\
\text { 1998) }\end{array}$ & $\begin{array}{l}\text { Low at birth in dogs, with increase } \\
\text { through } 3 \text { wk postnatal, and } \\
\text { secondary increase after weaning } \\
\text { (Buddington et al., 2003) }\end{array}$ \\
\hline
\end{tabular}


TABLE 7

Ontogeny of selected intestinal brush border hydrolases

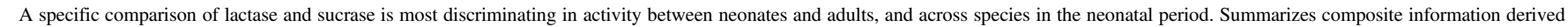
from RNA expression, protein expression, and/or enzyme activity.

\begin{tabular}{|c|c|c|c|c|}
\hline Enzyme & Human & Rat & Pig & Other \\
\hline $\begin{array}{l}\text { Lactase-phorizin } \\
\text { hydrolase }\end{array}$ & $\begin{array}{l}\text { Present and functional at birth; } \\
\text { typically declines after } \\
\text { weaning, but variable in } \\
\text { different populations } \\
\text { (Montgomery et al., 1991) }\end{array}$ & $\begin{array}{l}\text { Transcribed from birth in jejunum with } \\
\text { transient expression in ileum and } \\
\text { colon (Freund et al., 1990) } \\
\text { Rapid increase in activity in jejunum } \\
\text { and colon during 1st week } \\
\text { postnatally, with subsequent decline } \\
\text { at weaning (Henning, 1981; Foltzer- } \\
\text { Jourdainne and Raul, 1990) }\end{array}$ & $\begin{array}{l}\text { Present in late gestation and active } \\
\text { at birth but activity decreases in } \\
\text { second postnatal week } \\
\text { (Shulman et al., 1988; Tivey et al., } \\
\text { 1994; Buddington and Malo, } \\
\text { 1996; Wang and Xu, 1996; } \\
\text { Burrin et al., 2001) }\end{array}$ & $\begin{array}{l}\text { Low at birth with subsequent } \\
\text { increase in dogs } \\
\text { (Buddington et al., 2003) }\end{array}$ \\
\hline $\begin{array}{l}\text { Sucrase-isomaltase } \\
\text { complex }\end{array}$ & $\begin{array}{l}\text { Synthesized as pro-form in utero, } \\
\text { but not functional until } \\
\text { approximately GW 26; also } \\
\text { transiently expressed in colon } \\
\text { of neonates (Triadou and } \\
\text { Zweibaum, 1985) }\end{array}$ & $\begin{array}{l}\text { RNA not detected in neonates; Activity } \\
\text { low or not detected until PND } 14 \text { in } \\
\text { small intestine, but increases rapidly } \\
\text { through weaning (PND 21); } \\
\text { transiently expressed in colon near } \\
\text { weaning (Henning, 1981; Toofanian, } \\
\text { 1984; Foltzer-Jourdainne et al., } \\
\text { 1989; Galand, 1989; Freund et al., } \\
\text { 1990; Leeper and Henning, 1990) }\end{array}$ & $\begin{array}{l}\text { Present at birth with increase in } \\
\text { activity during second postnatal } \\
\text { week (James et al., 1987; } \\
\text { Shulman et al., 1988; Smith, } \\
\text { 1988) }\end{array}$ & $\begin{array}{l}\text { Present at birth in dogs but no } \\
\text { rabbits; increased activity } \\
\text { at weaning (Galand, 1989) }\end{array}$ \\
\hline
\end{tabular}

during the suckling period (Leeper and Henning, 1990). Across species, with introduction of solid foods and eventual weaning, the distribution and activity of intestinal enzymes largely mimic that of adults.

\section{Neonatal Microbiome}

There have been several recent publications that have explored the timing and impact of perinatal microbial colonization, including relationships to disease risk both in infancy and later in life (Arrieta et al., 2014; Sherman et al., 2015; Miller, 2016; Macpherson et al., 2017) With the advent of genomic, rather than culture-based, investigations, the dogma of a sterile uterine environment during pregnancy has been challenged. It is widely accepted that there is a placental microbiome, amniotic fluid is not always sterile, and that there are also differences in the initial infant microbiome between vaginal and cesarean section birth (Arrieta et al., 2014; Gritz and Bhandari, 2015a,b). The role of the microbiome can be especially critical for preterm neonates, as they are more prone to develop postnatal infections requiring antibiotic use, and are also likely to acquire atypical, pathogenic, or inadequate intestinal flora in the perinatal period (Arrieta et al., 2014; Gritz and Bhandari, 2015a,b; DiBartolomeo and Claud, 2016; Vinturache et al., 2016; Stewart et al., 2017).

A recent review (Lim et al., 2016) demonstrates that, relative to adults, the neonatal microbiome and virome have relatively low diversity and stability, but high interindividual variability. Although the establishment of the gut microbiome is an important feature of postnatal development, it is likely that the establishment of a robust mixture of commensal organisms is more critical than colonization by any specific bacterial species. There is a complex relationship among the maternal, nutritional, and developmental events that surround the seeding of the neonatal microbiome (Miller, 2016; Ganal-Vonarburg et al., 2017). These events have also been evaluated to some extent in neonates of nonclinical species, including the rat (Kennedy et al., 2016; Ganal-Vonarburg et al., 2017), dog (Guard et al., 2017), pig (Saraf et al., 2017), and rhesus macaque (Ardeshir et al., 2014).

When considering the ADME characteristics of the neonatal gastrointestinal system, it is important to also consider the potential role of the neonatal microbiome. This is especially important given the relatively high risk of infection in neonates, the current use of peripartum antimicrobial agents in mothers and neonates, and the potential role of microbiota in the metabolism of both nutrients and medicines (Sherman et al., 2014; Kennedy et al., 2016; Macpherson et al., 2017; Nogacka et al., 2017).

\section{Excretion}

The principal route of excretion via the GIT is directly through the feces, and requires adequate motility. In neonatal rats, maternal stimulation is needed for both urination and defecation (Henning, 1981). Many drivers similar to those discussed above for absorption also apply to excretion; that is, what is not absorbed is excreted in the feces. In addition, some drugs may be excreted in the feces via the bile after metabolic conjugation in the liver. Although bile conjugates are not readily resorbed, free bilirubin and bile salts may be passively absorbed in the small intestine, especially early in the postnatal period, in both altricial species, like the rat, and precocious species, like the guinea pig (Little and Lester, 1980; Heubi and Fondacaro, 1982). Active transport of bile salts in the ileum is contingent on the expression of the ASBT, which is active at birth in the guinea pig (Heubi and Fondacaro, 1982), but not until weaning in the rat and rabbit (Little and Lester, 1980; Barnard et al., 1985; Moyer et al., 1988; Shneider et al., 1997). A detailed review of enterohepatic bile circulation is beyond the scope of this review, but the development and activity of intestinal transporters in general, in addition to hepatic bile production and conjugation reactions, can contribute to drug and/or chemical disposition, as has been previously reviewed (Staggers et al., 1982; Pácha, 2000; Drozdowski et al., 2010; Brouwer et al., 2015; Karpen and Karpen, 2017). Thus, for lipophilic chemicals and drugs that are primarily excreted through the bile, the physiologic maturation of these pathways must be considered for both human neonates and species used for toxicity testing.

\section{Predicting Oral Absorption of Chemicals and Drugs}

Predicting the rate and extent of oral absorption of drugs remains a challenge for adult laboratory animals and humans (Burton et al., 2002). The use of Caco- 2 cells to characterize the intestinal permeability of drugs and nutrients has received much attention (Turco et al., 2011; Poquet and Wooster, 2016). This in vitro system has successes as well as shortcomings in predicting in vivo oral absorption rates (Larregieu and Benet, 2013). Caco-2 cells characterize the transcellular movement of lipophilic compounds, which diffuse across the mucus layer and enterocytes, and paracellular diffusion for low-molecular weight hydrophilic compounds, which cross intercellular tight junctions between the enterocytes. Paracellular transport is much less efficient than transcellular because of the limited surface area of intercellular tight junctions in vivo. Caco-2 cells also retain apical and basolateral transporters. 
These transporters, in a complex interplay with both active and passive processes in the intestinal epithelium, act on hydrophilic compounds, resulting in a net flux of the majority of the drug back to the lumen of the GIT or into the portal blood supply.

Findings from the Caco-2 cells bout intestinal permeability have been incorporated in advanced compartmental and transit (Gobeau et al., 2016), or similar, algorithms, which are complex sets of equations describing key features of the GIT as a drug is emptied from the stomach (gastric emptying time) into the small intestine. Ultimately, the advanced compartmental and transit algorithms predict the concentration of drug that is transported across the intestinal epithelium by mechanisms previously described at a rate determined empirically by Caco- 2 cells. Some of the quantitative parameters in these algorithms are intestinal transit time, $\mathrm{pH}$ gradient in the GIT to estimate dissolution rates, surface area, and intestinal permeability. More advanced computational features of the GIT may include metabolism in the mucosa and lumen and membrane transporters. Once the drug has crossed the intestinal enterocytes into the portal blood supply (or lymph system) other computational tools, such as compartmental or physiologic-based pharmacokinetic (PBPK) models, are used to describe the whole-body distribution of the drug.

These empirical and/or computational technologies, which were created to better understand and predict oral absorption, have been applied to adults, children, neonates (Parrott et al., 2011; Abduljalil et al., 2014; Duan et al., 2017), and adult rats (Willmann et al., 2003; Pade et al., 2017). Models for oral drug absorption for neonates and infants represent an emerging field. Authors have reported a need to develop an in vitro dissolution test that reflects the $\mathrm{pH}$ of the gastric and intestinal fluids in the neonate (Villiger et al., 2016). Gastric emptying has been reported to be slower in neonates and infants than in adults, whereas for older children model predictions and observations were in adequate agreement without adjustment of gastric emptying (Khalil and Laer, 2014). There is a dearth of experimental data reported using immature Caco-2 cells, which represent immature stages of intestinal development. Ohrvik et al. (2013) reported on using immature Caco-2 cells to understand why newborns have a higher gastrointestinal uptake of cadmium than adults. They found upregulation of an efflux transporter MRP1 gene expression and increased activity of the protein MRP1, an efflux transporter. These results may explain why cadmium oral absorption is greater in the very young (Ohrvik et al., 2013). Several authors have used Caco- 2 cells to study the translocation of fatty acids, which has been summarized by Poquet and Wooster (2016). However, the utility of Caco- 2 cells or another cell line (IEC-6) to evaluate the transport of fatty acids in the enterocyte has been questioned (Poquet and Wooster, 2016, their Table 5).

For chemicals, PBPK models for nursing by newborn laboratory animals and humans have been constructed assuming that chemicals equilibrate with mammary gland milk and the chemical in milk either diffuses back into systemic maternal circulation or is ingested by the nursing infant or laboratory animal pup. Once ingested into the stomach, the oral bioavailability of the chemical may be assumed to be $100 \%$ or is adjusted to less than $100 \%$ based on experimental evidence. This approach has provided agreement between observations and predictions for laboratory animals (Corley et al., 2003; Clewell et al., 2008; Lin et al., 2013).

For direct oral dosing of rat pups, a few articles on PBPK modeling estimated oral absorption and expressed the rate of uptake as first-order rate constants. These estimates were based on fit to predict the systemic appearance of the administered chemical after bolus dosing. This is usually carried out using a compartment for the stomach (absorption and gastric emptying) and another compartment representing the small intestine (absorption, first-order rate constant, per hour). For bisphenol
A, a well-metabolized chemical, the apparent PBPK model-fitted firstorder oral uptake rate constant values decreased with pup age (PND 3, 10, and 21) into adulthood (Yang et al., 2013). This apparent decrease in oral uptake rate constant with age may simply reflect changes in the metabolic capacity of the GIT. In contrast, for ethanol, a nonlipophilic chemical with high water solubility, the apparent fitted oral uptake constant values remained the same until near weaning, at which time they increased slightly (Martin et al., 2015). This increase in first-order uptake rate constants near birth may be related to increases in paracellular transport in the intestinal epithelium. In another PBPK modeling study, a single oral absorption value was used to describe the kinetics of a very lipophilic chemical, deltamethrin, in rat pups of varying ages after oral bolus gavage (Tornero-Velez et al., 2010). However, the lymphatic system and fecal excretion may confound the evaluation for oral absorption of deltamethrin.

The successful application of neonatal physiologic parameters into PBPK models for orally administered drugs would be of great benefit, given the difficulty in studying neonatal pharmacokinetics empirically. A recent publication (Johnson et al., 2018) describes the incorporation of age-specific considerations in the algorithms of the Simcyp, Ltd. (Sheffield, UK), Advanced Dissolution, Absorption and Metabolism model. Although this model has been applied only in the evaluation of paracetamol, theophylline, and ketoconazole kinetics in pediatrics, the expansion of such applications and continued validation will ultimately determine the relevance and breadth of utility for use in neonates.

\section{Discussion}

There is a need for the neonatology, nutrition, clinical pharmacology, toxicology, and PBPK modeling communities to combine their expertise to progress on research that will serve the newborn patient in the area of pharmacological management. In this review, the focus was on evaluating the ontogeny of the GIT with respect to factors that could impact ADME of drugs in neonates. Aspects of GIT development contributing to absorption in the neonatal period are consistently recognized as pharmacologically important in reviews of neonatal pharmacology. Predicting absorption, however, depends on other important and variable factors driving functional postnatal development of the GIT. This is highlighted by the literature surrounding the importance of the initiation of enteral feeding, the role of nutritional drivers of maturation, and the critical role of effective microbial colonization. Although the literature surveyed for this review is extensive, there are challenges in assembling a clear and consistent picture from the available data.

Much of our accumulated knowledge of the development and function of the neonatal GIT is derived from studies in laboratory animals. These studies may be necessary for the nonclinical evaluation of drugs intended for use in neonates. However, there are also challenges related to species differences, some of which are recognizable in both the structure and function of gastrointestinal tissues that can result in differences in both ADME and toxicity attributes of drugs. This is of importance when selecting a species to use for juvenile toxicity testing and is also critical for the evaluation of toxicokinetics in animal studies and potential relevance to human neonates.

In a recent review of gastrointestinal ontogeny across species (Downes, 2018), the pig was considered the most appropriate species to model the human term neonate for pharmacokinetics. The pig is an omnivorous species that is similar to humans in maturity of the GIT at birth; importantly, like humans, several digestive enzymes are active at birth and do not undergo large changes in activity during the suckling period (Shulman et al., 1988). Neonatal piglets have been extensively studied in areas of nutrition and gastrointestinal physiology, but to date 
have not been widely used in nonclinical toxicology or pharmacokinetic studies. Strain or type of pig should also be considered, as much of the nutritional literature revolves around studies conducted in piglets from typical large white "farm pig" stock (e.g., Landrace crosses). There are a few examples in the smaller "minipigs" (e.g., Hanford), but only sparse data from the pigs that have been most frequently used in toxicology studies, such as the Göttingen minipig (Van Peer et al., 2016). Thus, although substantial data on neonatal piglet physiology is available, it is important to also consider potential strain differences.

In contrast to the piglet, the neonatal rat may be more representative of the premature infant, as it is relatively immature at birth, reaching GIT functional equivalence with neonatal humans only late in the suckling period. For example, compared with humans, the neonatal rat is altricial at birth, grows very rapidly with high metabolic demand, and is heavily reliant on the efficient uptake of milk lipids and intact proteins for nutrition during suckling. As such, drugs that contain sugar or that increase blood sugar may not be well tolerated by neonatal rat pups. Likewise, exposure to orally administered lipophilic or protein-based drugs may exceed that of adult rats or neonatal humans because of relatively enhanced absorption and/or decreased elimination. Because of these differences, it can be difficult to interpret the translatability of toxicity signals from nonclinical studies to inform the appropriate evaluation of drugs in neonatal humans. In addition, collecting blood samples after the oral administration of chemicals or drugs in neonatal laboratory animals and humans remains a critical method to validate predictions of oral absorption models. However, in studies of rats and mice during the early postnatal period, terminal sampling is typically required to obtain sufficient blood volume for analysis. Therefore, serial sampling from individual animals is not feasible, and large numbers of animals per treatment group can be required to characterize pharmacokinetics on a population basis in studies with juvenile rodents.

With specific regard to the interpretation of ADME data, the physiologic and ontologic differences among the human, rat, and piglet neonatal GIT are particularly illustrative, and are therefore highlighted throughout our review. In summary, our review of the scientific literature regarding neonatal function of the GIT in humans and animals identified and provided information about the following major relevant areas of interest, and reached the following conclusions.

First, parameters such as gastric $\mathrm{pH}$, emptying rates, intestinal transit time, and activity of transporters and enzymes affect the potential bioavailability and ADME of orally administered drugs. In our review, we found that there is extensive literature for both humans and nonclinical species regarding the development of the intestinal tract form and function. However, the maturation of the intestine is highly variable in the normal state, and dependent on factors such as fed or fasted state, type of food, hormones, and intestinal microbiome. The integrated assessment of data can be further hampered by the diversity of approaches used to characterize ontology, which makes comparisons of results from multiple investigators challenging.

Second, an understanding of species-specific changes that occur in the neonatal period is important for appropriate nonclinical safety assessment. For example, although well studied in the liver, we do not fully understand the development of intestinal biotransformation reactions and ontogeny of intestinal transporters in nonclinical species. Also, the neonates of some nonclinical species, such as the pig, have been well studied under nutritional and surgical protocols, but have not been routinely used to study drugs. Overall, we need to critically assess the value of nonclinical in vivo studies for translational understanding of the ADME properties that drive exposures in neonates, especially for orally administered drugs. It is important to recognize the differences between species in terms of their size, metabolic demands, evolutionary diet (e.g., herbivore, carnivore, or omnivore), timing of dietary changes (e.g., weaning), maturity at birth, and even the type of placenta. Because of these differences, direct or linear translation across species is not possible, especially in the neonatal period, but the composite data can be useful in understanding maturation events critical for ADME processes.

Third, the impact of the neonatal microbiome on ADME of orally administered drugs is emerging as potentially important, but the specific impact remains unclear. Assessment of the role microbiome has not historically been a key consideration in drug development, but it is now being considered by some. As the technology and utility of microbiome data increase more generally, it will be important to recognize that the microbiome of the neonate is distinct from that of the older child or adult.

Finally, although the principles have been established and reviewed, there are currently limited primary pharmacokinetic data from pharmaceuticals administered to neonates. Often the PBPK tools are reviewed based on relatively limited physiologic and kinetic data that has been collected in a controlled experimental setting. Although the development of in vitro systems and pharmacokinetic modeling may be able to fill gaps in our ability to predict neonatal pharmacokinetics, continued assessment of these tools is warranted.

Overall, a strategic approach is needed to use the extensive GIT ontogeny information already available, selectively address knowledge gaps, and appropriately interpret nonclinical data to better inform the appropriate use of medicines in neonatal patients.

\section{Authorship Contributions}

Wrote or contributed to the writing of the manuscript: Neal-Kluever, Fisher, Grylack, Kakiuchi-Kiyota, Halpern.

\section{References}

Abduljalil K, Jamei M, Rostami-Hodjegan A, and Johnson TN (2014) Changes in individual drugindependent system parameters during virtual paediatric pharmacokinetic trials: introducing time-varying physiology into a paediatric PBPK model. AAPS J 16:568-576.

Abu-Raya B, Kollmann TR, Marchant A, and MacGillivray DM (2016) The immune system of HIV-exposed uninfected infants. Front Immunol 7:383.

Agunod M, Yamaguchi N, Lopez R, Luhby AL, and Glass GB (1969) Correlative study of hydrochloric acid, pepsin, and intrinsic factor secretion in newborns and infants. Am J Dig Dis 14:400-414.

Aiba T, Yoshinaga M, Ishida K, Takehara Y, and Hashimoto Y (2005) Intestinal expression and metabolic activity of the CYP3A subfamily in female rats. Biol Pharm Bull 28:311-315.

Allegaert K, van de Velde M, and van den Anker J (2014) Neonatal clinical pharmacology. Paediatr Anaesth 24:30-38.

Alnouti Y and Klaassen CD (2006) Tissue distribution and ontogeny of sulfotransferase enzymes in mice. Toxicol Sci 93:242-255.

Amdi C, Klarlund MV, Hales J, Thymann T, and Hansen CF (2016) Intrauterine growth-restricted piglets have similar gastric emptying rates but lower rectal temperatures and altered blood values when compared with normal-weight piglets at birth. J Anim Sci 94:4583-4590.

Ardeshir A, Narayan NR, Méndez-Lagares G, Lu D, Rauch M, Huang Y, Van Rompay KK, Lynch SV, and Hartigan-O'Connor DJ (2014) Breast-fed and bottle-fed infant rhesus macaques develop distinct gut microbiotas and immune systems. Sci Transl Med 6:252ra120.

Arévalo Sureda E, Weström B, Pierzynowski SG, and Prykhodko O (2016) Maturation of the intestinal epithelial barrier in neonatal rats coincides with decreased FcRn expression, replacement of vacuolated enterocytes and changed Blimp-1 expression [published correction appears in PLoS One (2017) 12:e169724]. PLoS One 11:e164775.

Armand M, Hamosh M, Mehta NR, Angelus PA, Philpott JR, Henderson TR, Dwyer NK, Lairon $D$, and Hamosh P (1996) Effect of human milk or formula on gastric function and fat digestion in the premature infant. Pediatr Res 40:429-437.

Arrieta MC, Stiemsma LT, Amenyogbe N, Brown EM, and Finlay B (2014) The intestinal microbiome in early life: health and disease. Front Immunol 5:427.

Atisook K and Madara JL (1991) An oligopeptide permeates intestinal tight junctions at glucoseelicited dilatations. Implications for oligopeptide absorption. Gastroenterology 100:719-724.

Avery GB, Randolph JG, and Weaver T (1966) Gastric acidity in the first day of life. Pediatrics 37:1005-1007.

Barbero GJ, Runge G, Fischer D, Crawford MN, Torres FE, and Gyorgy P (1952) Investigations on the bacterial flora, $\mathrm{pH}$, and sugar content in the intestinal tract of infants. J Pediatr 40:152-163. Barnard JA, Ghishan FK, and Wilson FA (1985) Ontogenesis of taurocholate transport by rat ileal brush border membrane vesicles. J Clin Invest 75:869-873.

Beach RC, Menzies IS, Clayden GS, and Scopes JW (1982) Gastrointestinal permeability changes in the preterm neonate. Arch Dis Child 57:141-145.

Berseth CL (1989) Gestational evolution of small intestine motility in preterm and term infants. J Pediatr 115:646-651.

Berseth CL (1990) Neonatal small intestinal motility: motor responses to feeding in term and preterm infants. J Pediatr 117:777-782.

Berseth CL (1992) Effect of early feeding on maturation of the preterm infant's small intestine. J Pediatr 120:947-953. 
Berseth CL and Nordyke C (1993) Enteral nutrients promote postnatal maturation of intestinal motor activity in preterm infants. Am J Physiol 264:G1046-G1051.

Betts S, Björkhem-Bergman L, Rane A, and Ekström L (2015) Expression of CYP3A4 and CYP3A7 in human foetal tissues and its correlation with nuclear receptors. Basic Clin Pharmacol Toxicol 117:261-266.

Blake MJ, Castro L, Leeder JS, and Kearns GL (2005) Ontogeny of drug metabolizing enzymes in the neonate. Semin Fetal Neonatal Med 10:123-138.

Bodé S, Dreyer M, and Greisen G (2004) Gastric emptying and small intestinal transit time in preterm infants: a scintigraphic method. J Pediatr Gastroenterol Nutr 39:378-382.

Boillat CS, Gaschen FP, Gaschen L, Stout RW, and Hosgood GL (2010a) Variability associated with repeated measurements of gastrointestinal tract motility in dogs obtained by use of a wireless motility capsule system and scintigraphy. Am J Vet Res 71:903-908.

Boillat CS, Gaschen FP, and Hosgood GL (2010b) Assessment of the relationship between body weight and gastrointestinal transit times measured by use of a wireless motility capsule system in dogs. Am J Vet Res 71:898-902.

Bonner JJ, Vajjah P, Abduljalil K, Jamei M, Rostami-Hodjegan A, Tucker GT, and Johnson TN (2015) Does age affect gastric emptying time? A model-based meta-analysis of data from premature neonates through to adults. Biopharm Drug Dispos 36:245-257.

Boudry G, David ES, Douard V, Monteiro IM, Le Huërou-Luron I, and Ferraris RP (2010) Role of intestinal transporters in neonatal nutrition: carbohydrates, proteins, lipids, minerals, and vitamins. J Pediatr Gastroenterol Nutr 51:380-401.

Bouras EP, Burton DD, Camilleri M, Stephens DA, and Thomforde GM (2004) Effect of cyclooxygenase-2 inhibitors on gastric emptying and small intestinal transit in humans. Neurogastroenterol Motil 16:729-735.

Bourlieu C, Ménard O, Bouzerzour K, Mandalari G, Macierzanka A, Mackie AR, and Dupont D (2014) Specificity of infant digestive conditions: some clues for developing relevant in vitro models. Crit Rev Food Sci Nutr 54:1427-1457.

Bowman CJ, Breslin WJ, Connor AV, Martin PL, Moffat GJ, Sivaraman L, Tornesi MB, and Chivers S (2013) Placental transfer of Fc-containing biopharmaceuticals across species, an industry survey analysis. Birth Defects Res B Dev Reprod Toxicol 98:459-485.

Brouwer KL, Aleksunes LM, Brandys B, Giacoia GP, Knipp G, Lukacova V, Meibohm B, Nigam SK, Rieder M, and de Wildt SN; Pediatric Transporter Working Group (2015) Human ontogeny of drug transporters: review and recommendations of the pediatric transporter working group. Clin Pharmacol Ther 98:266-287.

Buddington RK (1992) Intestinal nutrient transport during ontogeny of vertebrates. Am J Physiol 263:R503-R509.

Buddington RK (1994) Nutrition and ontogenetic development of the intestine. Can J Physiol Pharmacol 72:251-259.

Buddington RK and Diamond JM (1989) Ontogenetic development of intestinal nutrient transporters. Annu Rev Physiol 51:601-619.

Buddington RK, Elnif J, Malo C, and Donahoo JB (2003) Activities of gastric, pancreatic, and intestinal brush-border membrane enzymes during postnatal development of dogs. Am J Vet Res 64:627-634.

Buddington RK, Elnif J, Puchal-Gardiner AA, and Sangild PT (2001) Intestinal apical amino acid absorption during development of the pig. Am J Physiol Regul Integr Comp Physiol 280: R241-R247.

Buddington RK and Malo C (1996) Intestinal brush-border membrane enzyme activities and transport functions during prenatal development of pigs. J Pediatr Gastroenterol Nutr 23:51-64.

Buddington RK and Malo C (2003) Postnatal development of nutrient transport in the intestine of dogs. Am J Vet Res 64:635-645.

Buddington RK and Sangild PT (2011) Companion animals symposium: development of the mammalian gastrointestinal tract, the resident microbiota, and the role of diet in early life. J Anim Sci 89:1506-1519.

Buddington RK, Sangild PT, Hance B, Huang EY, and Black DD (2012) Prenatal gastrointestinal development in the pig and responses after preterm birth. J Anim Sci 90 (Suppl 4):290-298.

Burrin DG, Stoll B, Fan MZ, Dudley MA, Donovan SM, and Reeds PJ (2001) Oral IGF-I alters the posttranslational processing but not the activity of lactase-phlorizin hydrolase in formula-fed neonatal pigs. J Nutr 131:2235-2241.

Burton PS, Goodwin JT, Vidmar TJ, and Amore BM (2002) Predicting drug absorption: how nature made it a difficult problem. J Pharmacol Exp Ther 303:889-895.

Camilleri M and Linden DR (2016) Measurement of gastrointestinal and colonic motor functions in humans and animals. Cell Mol Gastroenterol Hepatol 2:412-428.

Carrière F, Raphel V, Moreau H, Bernadac A, Devaux MA, Grimaud R, Barrowman JA, Bénicourt C, Junien JL, Laugier R, et al. (1992) Dog gastric lipase: stimulation of its secretion in vivo and cytolocalization in mucous pit cells. Gastroenterology 102:1535-1545.

Cashore WJ (2017) Neonatal bilirubin metabolism, in Fetal and Neonatal Physiology (Polin RA Abman SH, Rowitch DH, Benitz WE, and Fox EA eds) pp 929-933, Elsevier, Philadelphia.

Cavell B (1979) Gastric emptying in preterm infants. Acta Paediatr Scand 68:725-730.

Cavell B (1981) Gastric emptying in infants fed human milk or infant formula. Acta Paediatr Scand 70:639-641.

Cavell B (1982) Reservoir and emptying function of the stomach of the premature infant. Acta Paediatr Scand Suppl 296:60-61.

Chastant-Maillard S, Freyburger L, Marcheteau E, Thoumire S, Ravier JF, and Reynaud K (2012) Timing of the intestinal barrier closure in puppies. Reprod Domest Anim 47 (Suppl 6):190-193.

Chen YT, Trzoss L, Yang D, and Yan B (2015) Ontogenic expression of human carboxylesterase-2 and cytochrome P450 3A4 in liver and duodenum: postnatal surge and organ-dependent regulation. Toxicology 330:55-61.

Cheng MM, Huang CF, Yang LY, Lin YG, Peng HJ, Chang CY, Sheng CC, and Wu TC (2012) Development of serum IgA and IgM levels in breast-fed and formula-fed infants during the first week of life. Early Hum Dev 88:743-745.

Cizkova K, Konieczna A, Erdosova B, and Ehrmann J (2014) Time-dependent expression of cytochrome p450 epoxygenases during human prenatal development. Organogenesis 10:53-61.

Clewell RA, Kremer JJ, Williams CC, Campbell JL Jr, Andersen ME, and Borghoff SJ (2008) Tissue exposures to free and glucuronidated monobutylyphthalate in the pregnant and fetal rat following exposure to di-n-butylphthalate: evaluation with a PBPK model. Toxicol Sci 103: 241-259.

Clowse ME, Förger F, Hwang C, Thorp J, Dolhain RJ, van Tubergen A, Shaughnessy L, Simpson J, Teil M, Toublanc N, et al. (2017) Minimal to no transfer of certolizumab pegol into breas milk: results from CRADLE, a prospective, postmarketing, multicentre, pharmacokinetic study. Ann Rheum Dis 76:1890-1896.
Commare CE and Tappenden KA (2007) Development of the infant intestine: implications for nutrition support. Nutr Clin Pract 22:159-173.

Corley RA, Mast TJ, Carney EW, Rogers JM, and Daston GP (2003) Evaluation of physiologically based models of pregnancy and lactation for their application in children's health risk assessments. Crit Rev Toxicol 33:137-211.

Coughtrie MW (2015) Ontogeny of human conjugating enzymes. Drug Metab Lett 9:99-108.

Cranwell PD (1985) The development of acid and pepsin (EC 3.4.23.1) secretory capacity in the pig; the effects of age and weaning. 1. Studies in anaesthetized pigs. Br J Nutr 54:305-320.

Cuzzolin L and Agostino R (2016) Off-label and unlicensed drug treatments in neonatal intensive care units: an Italian multicentre study. Eur J Clin Pharmacol 72:117-123.

de Passillé AM, Pelletier G, Ménard J, and Morisset J (1989) Relationships of weight gain and behavior to digestive organ weight and enzyme activities in piglets. J Anim Sci 67:2921-2929.

De Schaepdrijver LM, Annaert PPJ, and Chen CL (2018) Ontogeny of ADME processes during postnatal development in man and preclinical species: a comprehensive review. Drug Metab Dispos, in press.

de Zwart LL, Haenen HE, Versantvoort CH, Wolterink G, van Engelen JG, and Sips AJ (2004) Role of biokinetics in risk assessment of drugs and chemicals in children. Regul Toxicol Pharmacol 39:282-309.

Demers-Mathieu V, Underwood MA, Beverly RL, and Dallas DC (2018) Survival of immunoglobulins from human milk to preterm infant gastric samples at 1,2 , and $3 \mathrm{~h}$ postprandial. Neonatology 114:242-250.

DeNigris SJ, Hamosh M, Kasbekar DK, Lee TC, and Hamosh P (1988) Lingual and gastric lipases: species differences in the origin of prepancreatic digestive lipases and in the localization of gastric lipase. Biochim Biophys Acta 959:38-45.

Deren JS (1971) Development of structure and function in the fetal and newborn stomach. Am J Clin Nutr 24:144-159.

Diakidou A, Vertzoni M, Goumas K, Söderlind E, Abrahamsson B, Dressman J, and Reppas C (2009) Characterization of the contents of ascending colon to which drugs are exposed after oral administration to healthy adults. Pharm Res 26:2141-2151.

DiBartolomeo ME and Claud EC (2016) The developing microbiome of the preterm infant. Clin Ther 38:733-739.

DiPalma J, Kirk CL, Hamosh M, Colon AR, Benjamin SB, and Hamosh P (1991) Lipase and pepsin activity in the gastric mucosa of infants, children, and adults. Gastroenterology 101:116-121.

Downes NJ (2018) Consideration of the development of the gastrointestinal tract in the choice of species for regulatory juvenile studies. Birth Defects Res 110:56-62.

Dressman JB, Berardi RR, Dermentzoglou LC, Russell TL, Schmaltz SP, Barnett JL, and Jarvenpaa KM (1990) Upper gastrointestinal (GI) pH in young, healthy men and women. Pharm Res 7:756-761.

Drozdowski LA, Clandinin T, and Thomson AB (2010) Ontogeny, growth and development of the small intestine: understanding pediatric gastroenterology. World J Gastroenterol 16:787-799.

Duan P, Fisher JW, Yoshida K, Zhang L, Burckart GJ, and Wang J (2017) Physiologically based pharmacokinetic prediction of linezolid and emtricitabine in neonates and infants. Clin Pharmacokinet 56:383-394.

Edginton AN (2010) Oral drug absorption in pediatric populations, in Oral Drug Absorption: Prediction and Assessment (Dressman J ed) pp 108-126, Informa Healthcare, London.

Emoto C, Yoda N, Uno Y, Iwasaki K, Umehara K, Kashiyama E, and Yamazaki H (2013) Comparison of p450 enzymes between cynomolgus monkeys and humans: p450 identities, protein contents, kinetic parameters, and potential for inhibitory profiles. Curr Drug Metab 14:239-252.

Fakhoury M, de Beaumais T, Guimiot F, Azougagh S, Elie V, Medard Y, Delezoide AL, and Jacqz-Aigrain E (2009) mRNA expression of MDR1 and major metabolising enzymes in human fetal tissues. Drug Metab Pharmacokinet 24:529-536.

Fakhoury M, Litalien C, Medard Y, Cavé H, Ezzahir N, Peuchmaur M, and Jacqz-Aigrain E (2005) Localization and mRNA expression of CYP3A and P-glycoprotein in human duodenum as a function of age. Drug Metab Dispos 33:1603-1607.

Fernandez E, Perez R, Hernandez A, Tejada P, Arteta M, and Ramos JT (2011) Factors and mechanisms for pharmacokinetic differences between pediatric population and adults. Pharmaceutics 3:53-72.

Foltzer-Jourdainne C, Kedinger M, and Raul F (1989) Perinatal expression of brush-border hydrolases in rat colon: hormonal and tissue regulations. Am J Physiol 257:G496-G503.

Foltzer-Jourdainne C and Raul F (1990) Effect of epidermal growth factor on the expression of digestive hydrolases in the jejunum and colon of newborn rats. Endocrinology 127: $1763-1769$

Forsyth JS, Donnet L, and Ross PE (1990) A study of the relationship between bile salts, bile saltstimulated lipase, and free fatty acids in breast milk: normal infants and those with breast milk jaundice. J Pediatr Gastroenterol Nutr 11:205-210.

Forsyth JS, Ross PE, and Bouchier IA (1983) Bile salts in breast milk. Eur J Pediatr 140:126-127. Fredrikzon B and Hernell O (1977) Role of feeding on lipase activity in gastric contents. Acta Paediatr Scand 66:479-484.

Fredrikzon B, Hernell O, and Bläckberg L (1982) Lingual lipase. Its role in lipid digestion in infants with low birthweight and/or pancreatic insufficiency. Acta Paediatr Scand Suppl 296:75-80.

Fredrikzon B and Olivecrona T (1978) Decrease of lipase and esterase activities in intestinal contents of newborn infants during test meals. Pediatr Res 12:631-634.

Freed LM, York CM, Hamosh P, Mehta NR, and Hamosh M (1987) Bile salt-stimulated lipase of human milk: characteristics of the enzyme in the milk of mothers of premature and full-term infants. J Pediatr Gastroenterol Nutr 6:598-604.

Freund JN, Torp N, Duluc I, Foltzer-Jourdainne C, Danielsen M, and Raul F (1990) Comparative expression of the mRNA for three intestinal hydrolases during postnatal development in the rat. Cell Mol Biol 36:729-736.

Fu D, Yang H, Kong X, Blachier F, Wang W, and Yin Y (2013) Molecular cloning and expression profiling of excitatory amino acid carrier 1 in suckling Huanjiang mini-piglets with large or small body weight at birth. Mol Biol Rep 40:3341-3350.

Fujiwara R, Chen S, Karin M, and Tukey RH (2012) Reduced expression of UGT1A1 in intestines of humanized UGT1 mice via inactivation of NF- $\mathrm{BB}$ leads to hyperbilirubinemia. Gastroenterology 142:109-118.e2.

Fujiwara R, Maruo Y, Chen S, and Tukey RH (2015) Role of extrahepatic UDPglucuronosyltransferase 1A1: advances in understanding breast milk-induced neonatal hyperbilirubinemia. Toxicol Appl Pharmacol 289:124-132. 
Furihata C, Kawachi T, and Sugimura T (1972) Premature induction of pepsinogen in developing rat gastric mucosa by hormones. Biochem Biophys Res Commun 47:705-711.

Galand G (1989) Brush border membrane sucrase-isomaltase, maltase-glucoamylase and trehalase in mammals. Comparative development, effects of glucocorticoids, molecular mechanisms, and phylogenetic implications. Comp Biochem Physiol B 94:1-11.

Ganal-Vonarburg SC, Fuhrer T, and Gomez de Agüero M (2017) Maternal microbiota and antibodies as advocates of neonatal health. Gut Microbes 8:479-485.

García-Blanco A, Vento M, Diago V, and Cháfer-Pericás C (2016) Reference ranges for cortisol and $\alpha$-amylase in mother and newborn saliva samples at different perinatal and postnatal periods. J Chromatogr B Analyt Technol Biomed Life Sci 1022:249-255.

Ghishan FK, Jenkins JT, and Younoszai MK (1980) Maturation of calcium transport in the rat small and large intestine. J Nutr 110:1622-1628.

Gobeau N, Stringer R, De Buck S, Tuntland T, and Faller B (2016) Evaluation of the GastroPlus advanced compartmental and transit (ACAT) model in early discovery. Pharm Res 33 2126-2139.

Goncharova K, Lozinska L, Arevalo Sureda E, Woliński J, Weström B, and Pierzynowski S (2017) Importance of neonatal immunoglobulin transfer for hippocampal development and behaviour in the newborn pig. PLoS One 12:e180002.

Graff J, Brinch K, and Madsen JL (2001) Gastrointestinal mean transit times in young and middleaged healthy subjects. Clin Physiol 21:253-259.

Griswold C and Shohl AT (1925) Gastric digestion in new-born infants. Am J Dis Child 30 $541-549$.

Gritz EC and Bhandari V (2015a) Corrigendum: the human neonatal gut microbiome: a brief review [published correction appears in Front Pediatr (2015) 3:17]. Front Pediatr 3:60.

Gritz EC and Bhandari V (2015b) The human neonatal gut microbiome: a brief review. Front Pediatr 3:17

Guard BC, Mila H, Steiner JM, Mariani C, Suchodolski JS, and Chastant-Maillard S (2017) Characterization of the fecal microbiome during neonatal and early pediatric development in puppies. PLoS One 12: 0175718.

Hamosh M, Henderson TR, and Hamosh P (1998) Gastric lipase and pepsin activities in the developing ferret: nonparallel development of the two gastric digestive enzymes. $J$ Pediatr Gastroenterol Nutr 26:162-166.

Hamosh M, Scanlon JW, Ganot D, Likel M, Scanlon KB, and Hamosh P (1981) Fat digestion in the newborn. Characterization of lipase in gastric aspirates of premature and term infants. $J$ Clin Invest 67:838-846.

Harada E, Kiriyama H, Kobayashi E, and Tsuchita H (1988) Postnatal development of biliary and pancreatic exocrine secretion in piglets. Comp Biochem Physiol A 91:43-51.

Harding JE, Cormack BE, Alexander T, Alsweiler JM, and Bloomfield FH (2017) Advances in nutrition of the newborn infant. Lancet 389:1660-1668.

Hauschner H, Rosenberg N, Seligsohn U, Mendelsohn R, Simmonds A, Shiff Y, Schachter Y, Aviner S, and Sharon N (2015) Persistent neonatal thrombocytopenia can be caused by IgA antiplatelet antibodies in breast milk of immune thrombocytopenic mothers. Blood 126: $661-664$

Heller J (1963) The role of emptying of the stomach in absorption of a water load in the rat during ontogenesis. Physiol Bohemoslov 12:526-532.

Henning SJ (1981) Postnatal development: coordination of feeding, digestion, and metabolism. Am J Physiol 241:G199-G214.

Hersman EM and Bumpus NN (2014) A targeted proteomics approach for profiling murine cytochrome P450 expression. J Pharmacol Exp Ther 349:221-228.

Heubi JE, Balistreri WF, and Suchy FJ (1982) Bile salt metabolism in the first year of life. J Lab Clin Med 100:127-136.

Heubi JE and Fondacaro JD (1982) Postnatal development of intestinal bile salt transport in the Guinea pig. Am J Physiol 243:G189-G194.

Hines RN (2013) Developmental expression of drug metabolizing enzymes: impact on disposition in neonates and young children. Int J Pharm 452:3-7.

Hipper K and Ehrlein HJ (2001) Motility of the large intestine and flow of digesta in pigs. Res Vet Sci 71:93-100.

Hosokawa M (2008) Structure and catalytic properties of carboxylesterase isozymes involved in metabolic activation of prodrugs. Molecules 13:412-431.

Hurley WL and Theil PK (2011) Perspectives on immunoglobulins in colostrum and milk. Nutrients 3:442-474.

Hussain I, Kellett L, Affleck J, Shepherd J, and Boyd R (2002) Expression and cellular distribution during development of the peptide transporter (PepT1) in the small intestinal epithelium of the rat. Cell Tissue Res 307:139-142.

ICRP (2002) Basic anatomical and physiological data for use in radiological protection: reference values. A report of age- and gender-related differences in the anatomical and physiological characteristics of reference individuals. ICRP Publication 89. Ann ICRP 32:5-265.

Ikezaki M and Johnson LR (1983) Development of sensitivity to different secretagogues in the rat stomach. Am J Physiol 244:G165-G170.

Iverson SJ, Kirk CL, Hamosh M, and Newsome J (1991) Milk lipid digestion in the neonatal dog: the combined actions of gastric and bile salt stimulated lipases. Biochim Biophys Acta 1083 109-119.

James PS, Smith MW, Tivey DR, and Wilson TJ (1987) Epidermal growth factor selectively increases maltase and sucrase activities in neonatal piglet intestine. $J$ Physiol 393:583-594.

Jensen MS, Jensen SK, and Jakobsen K (1997) Development of digestive enzymes in pigs with emphasis on lipolytic activity in the stomach and pancreas. J Anim Sci 75:437-445.

Johnson LR (1985) Functional development of the stomach. Annu Rev Physiol 47:199-215.

Johnson TN, Bonner JJ, Tucker GT, Turner DB, and Jamei M (2018) Development and applications of a physiologically-based model of paediatric oral drug absorption. Eur J Pharm Sci 115 $57-67$.

Johnson TN, Tanner MS, Taylor CJ, and Tucker GT (2001) Enterocytic CYP3A4 in a paediatric population: developmental changes and the effect of coeliac disease and cystic fibrosis. $\mathrm{Br} \mathrm{J} \mathrm{Clin}$ Pharmacol 51:451-460.

Johnson TN, Tanner MS, and Tucker GT (2000) A comparison of the ontogeny of enterocytic and hepatic cytochromes P450 3A in the rat. Biochem Pharmacol 60:1601-1610.

Jolin-Dahel K, Ferretti E, Montiveros C, Grenon R, Barrowman N, and Jimenez-Rivera C (2013) Parenteral nutrition-induced cholestasis in neonates: where does the problem lie? Gastroenterol Res Pract 2013:163632.

Kalhan SC and Bier DM (2008) Protein and amino acid metabolism in the human newborn. Аnпи Rev Nutr 28:389-410.
Kaplan MHC (2017) Hereditary contributions to neonatal bilirubinemia, in Fetal and Neonatal Physiology (Polin RA, Abman SH, Rowitch DH, Benitz WE, and Fox EA eds) pp 933-941, Elsevier, Philadelphia.

Kararli TT (1995) Comparison of the gastrointestinal anatomy, physiology, and biochemistry of humans and commonly used laboratory animals. Biopharm Drug Dispos 16:351-380.

Karpen HE and Karpen SJ (2017) Bile acid metabolism during development, in Fetal and Neonatal Physiology (Polin RA, Abman SH, Rowitch DH, Benitz WE, and Fox EA eds) pp 913-928, Elsevier, Philadelphia.

Kaye JL (2011) Review of paediatric gastrointestinal physiology data relevant to oral drug delivery. Int J Clin Pharm 33:20-24.

Kelly EJ, Newell SJ, Brownlee KG, Primrose JN, and Dear PR (1993) Gastric acid secretion in preterm infants. Early Hum Dev 35:215-220.

Kennedy RC, Fling RR, Robeson MS, Saxton AM, Donnell RL, Darcy JL, Bemis DA, Liu J, Zhao $\mathrm{L}$, and Chen J (2016) Temporal development of gut microbiota in triclocarban exposed pregnant and neonatal rats. Sci Rep 6:33430.

Khalil F and Läer S (2014) Physiologically based pharmacokinetic models in the prediction of oral drug exposure over the entire pediatric age range-sotalol as a model drug. AAPS $J$ 16:226-239. Klaassen CD and Aleksunes LM (2010) Xenobiotic, bile acid, and cholesterol transporters: function and regulation. Pharmacol Rev 62:1-96.

Klein CJ, Revenis M, Kusenda C, and Scavo L (2010) Parenteral nutrition-associated conjugated hyperbilirubinemia in hospitalized infants [published correction appears in J Am Diet Assoc (2011) 111:463]. J Am Diet Assoc 110:1684-1695.

Komura H and Iwaki M (2011) In vitro and in vivo small intestinal metabolism of CYP3A and UGT substrates in preclinical animals species and humans: species differences. Drug Metab Rev 43:476-498

Konieczna A, Erdösová B, Lichnovská R, Jandl M, Cížková K, and Ehrmann J (2011) Differential expression of ABC transporters (MDR1, MRP1, BCRP) in developing human embryos. J Mol Histol 42:567-574.

Koslo RJ, Burks TF, and Porreca F (1986) Centrally administered bombesin affects gastrointestinal transit and colonic bead expulsion through supraspinal mechanisms. J Pharmacol Exp Ther 238: $62-67$.

Kvetina J, Kunes M, Bures J, Kopacova M, Tachecí I, Spelda S, Herout V, and Rejchrt S (2008) The use of wireless capsule enteroscopy in a preclinical study: a novel diagnostic tool for indomethacin-induced gastrointestinal injury in experimental pigs. Neuroendocrinol Lett 29 $763-769$.

Lacroix B, Kedinger M, Simon-Assmann P, Rousset M, Zweibaum A, and Haffen K (1984) Developmental pattern of brush border enzymes in the human fetal colon. Correlation with some morphogenetic events. Early Hum Dev 9:95-103.

Laizure SC, Herring V, Hu Z, Witbrodt K, and Parker RB (2013) The role of human carboxylesterases in drug metabolism: have we overlooked their importance? Pharmacotherapy 33: 210-222.

Lange A, Funch-Jensen P, Thommesen P, and Schiøtz PO (1997) Gastric emptying patterns of a liquid meal in newborn infants measured by epigastric impedance. Neurogastroenterol Motil 9 : $55-62$.

Larregieu CA and Benet LZ (2013) Drug discovery and regulatory considerations for improving in silico and in vitro predictions that use Caco-2 as a surrogate for human intestinal permeability measurements. AAPS J 15:483-497.

Laughon MM, Avant D, Tripathi N, Hornik CP, Cohen-Wolkowiez M, Clark RH, Smith PB, and Rodriguez W (2014) Drug labeling and exposure in neonates. JAMA Pediatr 168:130-136. Lebenthal A and Lebenthal E (1999) The ontogeny of the small intestinal epithelium. JPEN J Parenter Enteral Nutr 23(5 Suppl):S3-S6.

Lebenthal E and Lee PC (1980) Development of functional responses in human exocrine pancreas. Pediatrics 66:556-560.

Lecce JG and Broughton CW (1973) Cessation of uptake of macromolecules by neonatal Guinea pig, hamster and rabbit intestinal epithelium (closure) and transport into blood. J Nutr 103: 744-750.

Lee CA, Neul D, Clouser-Roche A, Dalvie D, Wester MR, Jiang Y, Jones JP III, Freiwald S, Zientek M, and Totah RA (2010) Identification of novel substrates for human cytochrome P450 2J2. Drug Metab Dispos 38:347-356.

Lee PC, Borysewicz R, Struve M, Raab K, and Werlin SL (1993) Development of lipolytic activity in gastric aspirates from premature infants. J Pediatr Gastroenterol Nutr 17:291-297.

Leeper LL and Henning SJ (1990) Development and tissue distribution of sucrase-isomaltase mRNA in rats. Am J Physiol 258:G52-G58.

Li FC, Jiang YN, and Shen TF (2001) Development of lipase in nursing piglets. Proc Natl Sci Counc Repub China B 25:12-16.

Liao TH, Hamosh P, and Hamosh M (1983) Gastric lipolysis in the developing rat. Ontogeny of the lipases active in the stomach. Biochim Biophys Acta 754:1-9.

Lim ES, Wang D, and Holtz LR (2016) The bacterial microbiome and virome milestones of infant development. Trends Microbiol 24:801-810.

Lin Z, Fisher JW, Wang R, Ross MK, and Filipov NM (2013) Estimation of placental and lactational transfer and tissue distribution of atrazine and its main metabolites in rodent dams, fetuses, and neonates with physiologically based pharmacokinetic modeling. Toxicol Appl Pharmacol 273:140-158.

Lindquist S and Hernell O (2010) Lipid digestion and absorption in early life: an update. Curr Opin Clin Nutr Metab Care 13:314-320.

Little JM and Lester R (1980) Ontogenesis of intestinal bile salt absorption in the neonatal rat. Am J Physiol 239:G319-G323.

Lu L, Li T, Williams G, Petit E, Borowsky M, and Walker WA (2011) Hydrocortisone induces changes in gene expression and differentiation in immature human enterocytes. Am J Physiol Gastrointest Liver Physiol 300:G425-G432.

Macpherson AJ, de Agüero MG, and Ganal-Vonarburg SC (2017) How nutrition and the materna microbiota shape the neonatal immune system. Nat Rev Immunol 17:508-517.

Maes BD, Ghoos YF, Geypens BJ, Hiele MI, and Rutgeerts PJ (1995) Relation between gastric emptying rate and energy intake in children compared with adults. Gut 36:183-188.

Maharaj AR and Edginton AN (2016) Examining small intestinal transit time as a function of age: is there evidence to support age-dependent differences among children? Drug Metab Dispos 44 $1080-1089$.

Martignoni M, Groothuis GM, and de Kanter R (2006) Species differences between mouse, rat, dog, monkey and human CYP-mediated drug metabolism, inhibition and induction. Expert Opin Drug Metab Toxicol 2:875-894. 
Martin SA, McLanahan ED, Bushnell PJ, Hunter ES III, and El-Masri H (2015) Species extrapolation of life-stage physiologically-based pharmacokinetic (PBPK) models to investigate the developmental toxicology of ethanol using in vitro to in vivo (IVIVE) methods. Toxicol Sci 143 : 512-535.

Mason S (1962) Some aspects of gastric function in the newborn. Arch Dis Child 37:387-391.

Matsubara T, Kim HJ, Miyata M, Shimada M, Nagata K, and Yamazoe Y (2004) Isolation an characterization of a new major intestinal CYP3A form, CYP3A62, in the rat. J Pharmacol Exp Ther 309:1282-1290.

McCarver DG and Hines RN (2002) The ontogeny of human drug-metabolizing enzymes: phase II conjugation enzymes and regulatory mechanisms. J Pharmacol Exp Ther 300:361-366.

Ménard D, Monfils S, and Tremblay E (1995) Ontogeny of human gastric lipase and pepsin activities. Gastroenterology 108:1650-1656.

Miclat NN, Hodgkinson R, and Marx GF (1978) Neonatal gastric pH. Anesth Analg 57:98-101.

Miki Y, Suzuki T, Tazawa C, Blumberg B, and Sasano H (2005) Steroid and xenobiotic receptor (SXR), cytochrome P450 3A4 and multidrug resistance gene 1 in human adult and fetal tissues. Mol Cell Endocrinol 231:75-85.

Mila H, Grellet A, Mariani C, Feugier A, Guard B, Suchodolski J, Steiner J, and Chastant-Maillard S (2017) Natural and artificial hyperimmune solutions: impact on health in puppies. Reprod Domest Anim 52 (Suppl 2):163-169.

Miller WB Jr (2016) The eukaryotic microbiome: origins and implications for fetal and neonatal life. Front Pediatr 4:96.

Miyamoto K, Shiraga T, Morita K, Yamamoto H, Haga H, Taketani Y, Tamai I, Sai Y, Tsuji A and Takeda E (1996) Sequence, tissue distribution and developmental changes in rat intestinal oligopeptide transporter. Biochim Biophys Acta 1305:34-38.

Moffat GJ, Retter MW, Kwon G, Loomis M, Hock MB, Hall C, Bussiere J, Lewis EM, and Chellman GJ (2014) Placental transfer of a fully human IgG2 monoclonal antibody in the cynomolgus monkey, rat, and rabbit: a comparative assessment from during organogenesis to late gestation. Birth Defects Res B Dev Reprod Toxicol 101:178-188.

Montgomery RK, Büller HA, Rings EH, and Grand RJ (1991) Lactose intolerance and the genetic regulation of intestinal lactase-phlorizin hydrolase. FASEB J 5:2824-2832.

Montgomery RK, Sybicki MA, and Grand RJ (1981) Autonomous biochemical and morphological differentiation in fetal rat intestine transplanted at 17 and 20 days of gestation. Dev Bio 87:76-84.

Mooij MG, de Koning BA, Huijsman ML, and de Wildt SN (2012) Ontogeny of oral drug absorption processes in children. Expert Opin Drug Metab Toxicol 8:1293-1303.

Mooij MG, de Koning BE, Lindenbergh-Kortleve DJ, Simons-Oosterhuis Y, van Groen BD, Tibboel D, Samsom JN, and de Wildt SN (2016) Human intestinal PEPT1 transporter expression and localization in preterm and term infants. Drug Metab Dispos 44:1014-1019.

Mooij MG, Schwarz UI, de Koning BA, Leeder JS, Gaedigk R, Samsom JN, Spaans E, van Goudoever JB, Tibboel D, Kim RB, et al. (2014) Ontogeny of human hepatic and intestina transporter gene expression during childhood: age matters. Drug Metab Dispos 42:1268-1274.

Moughan PJ, Cranwell PD, and Smith WC (1991) An evaluation with piglets of bovine milk, hydrolyzed bovine milk, and isolated soybean proteins included in infant milk formulas. II. Stomach-emptying rate and the postprandial change in gastric $\mathrm{pH}$ and milk-clotting enzyme activity. J Pediatr Gastroenterol Nutr 12:253-259.

Moyer MS, Goodrich AL, Rolfes MM, and Suchy FJ (1988) Ontogenesis of intestinal taurine transport: evidence for a beta-carrier in developing rat jejunum. Am J Physiol 254: G870-G877.

Mubiru JN and Xu RJ (1998) Comparison of growth and development of the exocrine pancreas in pigs and rats during the immediate postnatal period. Comp Biochem Physiol A Mol Integr Physiol 120:699-703.

Mudie DM, Murray K, Hoad CL, Pritchard SE, Garnett MC, Amidon GL, Gowland PA, Spille RC, Amidon GE, and Marciani L (2014) Quantification of gastrointestinal liquid volumes and distribution following a $240 \mathrm{~mL}$ dose of water in the fasted state. Mol Pharm 11:3039-3047.

Neu J (2007) Gastrointestinal maturation and implications for infant feeding. Early Hum Dev 83 $767-775$.

Nicolas JM, Bouzom F, Hugues C, and Ungell AL (2017) Oral drug absorption in pediatrics: the intestinal wall, its developmental changes and current tools for predictions. Biopharm Drug Dispos 38:209-230.

Nogacka A, Salazar N, Suárez M, Milani C, Arboleya S, Solís G, Fernández N, Alaez L, Hernández-Barranco AM, de Los Reyes-Gavilán CG, et al. (2017) Impact of intrapartum antimicrobial prophylaxis upon the intestinal microbiota and the prevalence of antibiotic resistance genes in vaginally delivered full-term neonates. Microbiome 5:93.

Nosworthy MG, Bertolo RF, and Brunton JA (2013) Ontogeny of dipeptide uptake and peptide transporter 1 (PepT1) expression along the gastrointestinal tract in the neonatal Yucatan miniature pig. Br J Nutr 110:275-281.

Ohrvik H, Tydén E, Artursson P, Oskarsson A, and Tallkvist J (2013) Cadmium transport in a model of neonatal intestinal cells correlates to MRP1 and not DMT1 or FPN1. ISRN Toxico 2013:892364.

Omari TI and Davidson GP (2003) Multipoint measurement of intragastric $\mathrm{pH}$ in healthy preterm infants. Arch Dis Child Fetal Neonatal Ed 88:F517-F520.

Pácha J (2000) Development of intestinal transport function in mammals. Physiol Rev 80 1633-1667.

Pade D, Jamei M, Rostami-Hodjegan A, and Turner DB (2017) Application of the MechPeff mode to predict passive effective intestinal permeability in the different regions of the rodent smal intestine and colon. Biopharm Drug Dispos 38:94-114.

Paine MF, Hart HL, Ludington SS, Haining RL, Rettie AE, and Zeldin DC (2006) The human intestinal cytochrome P450 "pie". Drug Metab Dispos 34:880-886.

Palmeira P, Quinello C, Silveira-Lessa AL, Zago CA, and Carneiro-Sampaio M (2012) IgG placental transfer in healthy and pathological pregnancies. Clin Dev Immunol 2012:985646.

Pappenheimer JR and Reiss KZ (1987) Contribution of solvent drag through intercellular junctions to absorption of nutrients by the small intestine of the rat. J Membr Biol 100:123-136.

Parrott N, Davies B, Hoffmann G, Koerner A, Lave T, Prinssen E, Theogaraj E, and Singer T (2011) Development of a physiologically based model for oseltamivir and simulation of pharmacokinetics in neonates and infants. Clin Pharmacokinet 50:613-623.

Patel HR, Hewer A, Hayes JD, Phillips DH, and Campbell FC (1998) Age-dependent change of metabolic capacity and genotoxic injury in rat intestine. Chem Biol Interact 113:27-37.

Petersen YM, Elnif J, Schmidt M, and Sangild PT (2002) Glucagon-like peptide 2 enhances maltase-glucoamylase and sucrase-isomaltase gene expression and activity in parenterally fed premature neonatal piglets. Pediatr Res 52:498-503.
Picut CA and Coleman GD (2016) Gastrointestinal tract, in Atlas of Histology of the Juvenile Rat (Parker GA and Picut CA eds) pp 127-171, Elsevier, Boston.

Pierzynowski SG, Weström BR, Svendsen J, Svendsen L, and Karlsson BW (1995) Development and regulation of porcine pancreatic function. Int J Pancreatol 18:81-94.

Poquet L and Wooster TJ (2016) Infant digestion physiology and the relevance of in vitro biochemical models to test infant formula lipid digestion. Mol Nutr Food Res 60:1876-1895.

Potter GD and Lester R (1984) The developing colon and nutrition. J Pediatr Gastroenterol Nutr 3 485-487.

Redman RS and Sreebny LM (1971) Morphologic and biochemical observations on the development of the rat parotid gland. Dev Biol 25:248-279.

Ridlon JM, Kang DJ, Hylemon PB, and Bajaj JS (2014) Bile acids and the gut microbiome. Curr Opin Gastroenterol 30:332-338.

Robberecht P, Deschodt-Lanckman M, Camus J, Bruylands J, and Christophe J (1971) Rat pancreatic hydrolases from birth to weaning and dietary adaptation after weaning. Am J Physiol 221 376-381.

Rodewald R (1976) pH-dependent binding of immunoglobulins to intestinal cells of the neonata rat. I Cell Biol 71:666-669.

Ruiz L, Espinosa-Martos I, García-Carral C, Manzano S, McGuire MK, Meehan CL, McGuire MA, Williams JE, Foster J, Sellen DW, et al. (2017) What's normal? Immune profiling of human milk from healthy women living in different geographical and socioeconomic settings. Front Immunol 8:696.

Sangild PT (2006) Gut responses to enteral nutrition in preterm infants and animals. Exp Biol Med (Maywood) 231:1695-1711.

Sangild PT, Petersen YM, Schmidt M, Elnif J, Petersen TK, Buddington RK, Greisen G, Michaelsen KF, and Burrin DG (2002) Preterm birth affects the intestinal response to parenteral and enteral nutrition in newborn pigs. J Nutr 132:3786-3794.

Saraf MK, Piccolo BD, Bowlin AK, Mercer KE, LeRoith T, Chintapalli SV, Shankar K, Badger TM, and Yeruva L (2017) Formula diet driven microbiota shifts tryptophan metabolism from serotonin to tryptamine in neonatal porcine colon. Microbiome 5:77.

Sarles J, Moreau H, and Verger R (1992) Human gastric lipase: ontogeny and variations in children. Acta Paediatr 81:511-513.

Savidge TC, Morey AL, Ferguson DJ, Fleming KA, Shmakov AN, and Phillips AD (1995) Human intestinal development in a severe-combined immunodeficient xenograft model. Differentiation $\mathbf{5 8}: 361-371$

Savilahti E, Järvenpää AL, and Räihä NC (1983) Serum immunoglobulins in preterm infants: comparison of human milk and formula feeding. Pediatrics 72:312-316.

Schanler RJ, Lau C, Hurst NM, and Smith EO (2005) Randomized trial of donor human milk versus preterm formula as substitutes for mothers' own milk in the feeding of extremely premature infants. Pediatrics 116:400-406.

Sevenhuysen GP, Holodinsky C, and Dawes C (1984) Development of salivary alpha-amylase in infants from birth to 5 months. Am J Clin Nutr 39:584-588.

Shen H, Smith DE, and Brosius FC III (2001) Developmental expression of PEPT1 and PEPT2 in rat small intestine, colon, and kidney. Pediatr Res 49:789-795.

Sherman MP, Minnerly J, Curtiss W, Rangwala S, and Kelley ST (2014) Research on neonata microbiomes: what neonatologists need to know. Neonatology 105:14-24.

Sherman MP, Zaghouani H, and Niklas V (2015) Gut microbiota, the immune system, and diet influence the neonatal gut-brain axis. Pediatr Res 77:127-135.

Shibata M, Kawai M, Matsukura T, Heike T, Okanoya K, and Myowa-Yamakoshi M (2013) Salivary biomarkers are not suitable for pain assessment in newborns. Early Hum Dev 89:503-506.

Shneider BL, Setchell KD, and Crossman MW (1997) Fetal and neonatal expression of the apical sodium-dependent bile acid transporter in the rat ileum and kidney. Pediatr Res 42:189-194.

Shulman RJ, Henning SJ, and Nichols BL (1988) The miniature pig as an animal model for the study of intestinal enzyme development. Pediatr Res 23:311-315.

Shulman RJ, Schanler RJ, Lau C, Heitkemper M, Ou CN, and Smith EO (1998a) Early feeding, antenatal glucocorticoids, and human milk decrease intestinal permeability in preterm infants. Pediatr Res 44:519-523.

Shulman RJ, Schanler RJ, Lau C, Heitkemper M, Ou CN, and Smith EO (1998b) Early feeding, feeding tolerance, and lactase activity in preterm infants. J Pediatr 133:645-649.

Skinner AV (2014) Neonatal pharmacology. Anaesth Intensive Care Med 15:7.

Smith LJ, Kaminsky S, and D'Souza SW (1986) Neonatal fat digestion and lingual lipase. Acto Paediatr Scand 75:913-918.

Smith MW (1988) Postnatal development of transport function in the pig intestine. Comp Biochem Physiol A 90:577-582.

Smits A, Annaert P, and Allegaert K (2013) Drug disposition and clinical practice in neonates: cross talk between developmental physiology and pharmacology. Int J Pharm 452:8-13.

Socha-Banasiak A, Pierzynowski S, Woliński J, Grujic D, Boryczka M, Grzesiak P, Szczurek P, Czkwianianc E, Westrom B, and Goncharova K (2017) The pig as a model for premature infants - the importance of immunoglobulin supplementation for growth and development. J Bio Regul Homeost Agents 31:87-92.

Somani AA, Thelen K, Zheng S, Trame MN, Coboeken K, Meyer M, Schnizler K, Ince I, Willmann S, and Schmidt S (2016) Evaluation of changes in oral drug absorption in preterm and term neonates for biopharmaceutics classification system (BCS) class I and II compounds. $\mathrm{Br} J$ Clin Pharmacol 81:137-147.

Sondheimer JM, Clark DA, and Gervaise EP (1985) Continuous gastric pH measurement in young and older healthy preterm infants receiving formula and clear liquid feedings. $J$ Pediatr Gastroenterol Nutr 4:352-355.

Spiessens C, Ceuterick L, Ponette E, Janssens J, and Lemli J (1988) Combined manometric and radiological study of the changes in colonic motility induced by sennosides in rats. Pharmacology 36 (Suppl 1):66-72.

Staggers JE, Frost SC, and Wells MA (1982) Studies on fat digestion, absorption, and transport in the suckling rat. III. Composition of bile and evidence for enterohepatic circulation of bile salts. J Lipid Res 23:1143-1151.

Stahl GE, Mascarenhas MR, Fayer JC, Shiau YF, and Watkins JB (1993) Passive jejunal bile salt absorption alters the enterohepatic circulation in immature rats. Gastroenterology 104:163-173. Steingoetter A, Fox M, Treier R, Weishaupt D, Marincek B, Boesiger P, Fried M, and Schwizer W (2006) Effects of posture on the physiology of gastric emptying: a magnetic resonance imaging study. Scand J Gastroenterol 41:1155-1164.

Stewart CJ, Embleton ND, Marrs ECL, Smith DP, Fofanova T, Nelson A, Skeath T, Perry JD, Petrosino JF, Berrington JE, et al. (2017) Longitudinal development of the gut microbiome and metabolome in preterm neonates with late onset sepsis and healthy controls. Microbiome 5:75. 
Struijs MC, Diamond IR, de Silva N, and Wales PW (2009) Establishing norms for intestinal length in children. J Pediatr Surg 44:933-938.

Teichberg S, Wapnir RA, Moyse J, and Lifshitz F (1992) Development of the neonatal rat small intestinal barrier to nonspecific macromolecular absorption. II. Role of dietary corticosterone. Pediatr Res 32:50-57.

Tivey DR, Le Dividich J, Herpin P, Brown D, and Dauncey MJ (1994) Differential effects of lipid and carbohydrate on enterocyte lactase activity in newborn piglets. Exp Physiol 79:189-201.

Toofanian F (1984) The fetal and postnatal development of small intestinal disaccharidases in the rabbit. Lab Anim Sci 34:268-271.

Tooley KL, Howarth GS, Butler RN, Lymn KA, and Penttila IA (2009) The effects of formula feeding on physiological and immunological parameters in the gut of neonatal rats. Dig Dis Sci 54:1432-1439.

Tornero-Velez R, Mirfazaelian A, Kim KB, Anand SS, Kim HJ, Haines WT, Bruckner JV, and Fisher JW (2010) Evaluation of deltamethrin kinetics and dosimetry in the maturing rat using a PBPK model. Toxicol Appl Pharmacol 244:208-217.

Triadou N and Zweibaum A (1985) Maturation of sucrase-isomaltase complex in human fetal smal and large intestine during gestation. Pediatr Res 19:136-138.

Trintis J, Donohue P, and Aucott S (2010) Outcomes of early parenteral nutrition for premature infants. J Perinatol 30:403-407.

Turco L, Catone T, Caloni F, Di Consiglio E, Testai E, and Stammati A (2011) Caco-2/TC7 cell line characterization for intestinal absorption: how reliable is this in vitro model for the prediction of the oral dose fraction absorbed in human? Toxicol In Vitro 25:13-20.

Van Booven D, Marsh S, McLeod H, Carrillo MW, Sangkuhl K, Klein TE, and Altman RB (2010) Cytochrome P450 2C9-CYP2C9. Pharmacogenet Genomics 20:277-281.

van Elburg RM, Fetter WP, Bunkers CM, and Heymans HS (2003) Intestinal permeability in relation to birth weight and gestational and postnatal age. Arch Dis Child Fetal Neonatal Ed 88 F52-F55.

Van Peer E, Downes N, Casteleyn C, Van Ginneken C, Weeren A, and Van Cruchten S (2016) Organ data from the developing Göttingen minipig: first steps towards a juvenile PBPK model. J Pharmacokinet Pharmacodyn 43:179-190.

Van Peer E, Verbueken E, Saad M, Casteleyn C, Van Ginneken C, and Van Cruchten S (2014) Ontogeny of CYP3A and P-glycoprotein in the liver and the small intestine of the Göttingen minipig: an immunohistochemical evaluation. Basic Clin Pharmacol Toxicol 114:387-394.

Vega YM, Puchal AA, and Buddington RK (1992) Intestinal amino acid and monosaccharide transport in suckling pigs fed milk replacers with different sources of carbohydrate. J Nutr $\mathbf{1 2 2}$ 2430-2439.

Villiger A, Stillhart C, Parrott N, and Kuentz M (2016) Using physiologically based pharmacokinetic (PBPK) modelling to gain insights into the effect of physiological factors on oral absorption in paediatric populations. AAPS $J$ 18:933-947.

Vinturache AE, Gyamfi-Bannerman C, Hwang J, Mysorekar IU, and Jacobsson B; Preterm Birth International Collaborative (PREBIC) (2016) Maternal microbiome-a pathway to preterm birth. Semin Fetal Neonatal Med 21:94-99.

Vreugdenhil G, Sinaasappel M, and Bouquet J (1986) A comparative study of the mouth to caecum transit time in children and adults using a weight adapted lactulose dose. Acta Paediatr Scand $\mathbf{7 5}$ 483-488.

Vukavić T (1984) Timing of the gut closure. J Pediatr Gastroenterol Nutr 3:700-703.
Wagner H (1961) The development to full functional maturity of the gastric mucosa and the kidneys in fetus and newborn. Biol Neonat 3:257-274.

Walthall K, Cappon GD, Hurtt ME, and Zoetis T (2005) Postnatal development of the gastrointestinal system: a species comparison. Birth Defects Res B Dev Reprod Toxicol 74:132-156.

Wang T and Xu RJ (1996) Effects of colostrum feeding on intestinal development in newborn pigs. Biol Neonate 70:339-348.

Wang W, Blachier F, Fu D, Pan J, Yang H, Guo J, Chu W, Kong X, and Yin Y (2013) Ontogenic expression of the amino acid transporter $\mathrm{b}(0,+) \mathrm{AT}$ in suckling Huanjiang piglets: effect of intrauterine growth restriction. $\mathrm{Br} J$ Nutr 110:823-830

Watchko JF, Daood MJ, Mahmood B, Vats K, Hart C, and Ahdab-Barmada M (2001) P-glycoprotein and bilirubin disposition. J Perinatol 21 (Suppl 1):S43-S47; discussion S59-S62.

Weihrauch D, Kanchanapoo J, Ao M, Prasad R, Piyachaturawat P, and Rao MC (2006) Weanling, but not adult, rabbit colon absorbs bile acids: flux is linked to expression of putative bile acid transporters. Am J Physiol Gastrointest Liver Physiol 290:G439-G450.

Weström B, Svendsen J, and Tagesson C (1984a) Intestinal permeability to polyethyleneglycol 600 in relation to macromolecular 'closure' in the neonatal pig. Gut 25:520-525.

Weström BR, Svendsen J, Ohlsson BG, Tagesson C, and Karlsson BW (1984b) Intestinal transmission of macromolecules (BSA and FITC-labelled dextrans) in the neonatal pig. Influence of age of piglet and molecular weight of markers. Biol Neonate 46:20-26.

Weström BR, Tagesson C, Leandersson P, Folkesson HG, and Svendsen J (1989) Decrease in intestinal permeability to polyethylene glycol 1000 during development in the pig. J Dev Physio 11:83-87.

Willmann S, Schmitt W, Keldenich J, and Dressman JB (2003) A physiologic model for simulating gastrointestinal flow and drug absorption in rats. Pharm Res 20:1766-1771.

Winter HS, Hendren RB, Fox CH, Russell GJ, Perez-Atayde A, Bhan AK, and Folkman J (1991) Human intestine matures as nude mouse xenograft. Gastroenterology 100:89-98.

Yang X, Doerge DR, and Fisher JW (2013) Prediction and evaluation of route dependent dosimetry of BPA in rats at different life stages using a physiologically based pharmacokinetic model. Toxicol Appl Pharmacol 270:45-59.

Yu G, Zheng QS, and Li GF (2014) Similarities and differences in gastrointestinal physiology between neonates and adults: a physiologically based pharmacokinetic modeling perspective AAPS J 16:1162-1166.

Zhang H, Malo C, and Buddington RK (1997) Suckling induces rapid intestinal growth and changes in brush border digestive functions of newborn pigs. J Nutr 127:418-426.

Zhu Y, Ding X, Fang C, and Zhang QY (2014) Regulation of intestinal cytochrome P450 expression by hepatic cytochrome P450: possible involvement of fibroblast growth factor 15 and impact on systemic drug exposure. Mol Pharmacol 85:139-147.

Zweibaum A, Hauri HP, Sterchi E, Chantret I, Haffen K, Bamat J, and Sordat B (1984) Immunohistological evidence, obtained with monoclonal antibodies, of small intestinal brush border hydrolases in human colon cancers and foetal colons. Int J Cancer 34:591-598.

Address correspondence to: Wendy Halpern, Genentech, Inc., 1 DNA Way, MS 441, South San Francisco, CA 94080. E-mail: halpern.wendy@gene.com 